\title{
Çalışanların Psikolojik Sermayesinin Kariyer Adaptasyonuna Etkisi
}

\author{
Necmiye Tülin İRGE* İbrahim YILDIRIM*** Hazem ASSALİ*** \\ ÖZET
}

Araştırma Makalesi

Psikolojik sermaye yoğun rekabet ortamında günümüz işletmelerinin rekabet avantajı elde etmeleri için dikkate almaları gereken önemli bir kavram haline gelmiştir. İşletme kaynakları arasında önemi oldukça büyük olan insan kaynakları ve örgütsel davranış alanlarına yeni bir bakış açısı getirmiştir. Kariyer adaptasyonu çalışanın mevcutta var olan veya tahmin edilebilen iş tanımları ve iş yaşamında önceden tahmin edilemeyen ve değişikliklerin neden olduğu belirsizlik durumlarıyla mücadele edebilmesidir. Bu çalı̧̧mada psikolojik sermayenin kariyer adaptasyonuna etkisi incelenerek, işletmelerde gerek işe alımlarda psikolojik sermayesi güçlü adayların tercih kriterlerinden olması gerekse mevcut çalışanın psikolojik sermayesini güçlendirerek kariyer adaptasyonu süreçlerinde etkin kullanılmasına katkı sağlanması amaçlanmıştır. Çalışmanın örneklemi İstanbul Avrupa yakasında sıvı temizlik ürünleri üretimi yapan firmalarda çalışan 122 kişiden oluşmaktadır. Yapılan regresyon analizi sonucuna göre; psikolojik sermayenin, zaman algısı ve bireysel yükümlülük üzerinde etkisi ile öz yeterlik, dayanıklık ve umudun, zaman algısı ve bireysel yükümlülük üzerinde etkisi tespit edilmiştir.

Geliş: 25.11 .2020

Kabul: 08.03.2021

Anahtar Kelimeler:

Psikolojik Sermaye,

Kariyer adaptasyonu,

İş adaptasyonu,

İş uyumu

\section{The Effect of Employees' Psychological Capital On Career Adaptation}

\section{ABSTRACT}

Psychological capital has become an important concept that today's enterprises must take into account in order to gain a competitive advantage in an intense competitive environment. It has brought a new perspective to the areas of human resources and organizational behavior, which are very important. Career adaptation is the ability to combat existing or predictable job descriptions and situations of uncertainty caused by unpredictable and changes in work life. In this study, by examining the effect of psychological capital on career adaptation, it is aimed to be among the selection criteria of candidates with strong psychological capital in recruitment, and to contribute to the effective use of the existing employee's psychological capital in career adaptation processes. The sample of the research consists of 122 people working in companies producing liquid cleaning products in the European side of İstanbul. According to the results of simple and multiple regression analysis, the effect of psychological capital on time perception and individual obligation and the effect of selfsufficiency, endurance and hope on time and individual obligation were determined.

Research Article

Received: 25.11 .2020

Accepted: 08.03.2021

Keywords:

Psychological Capital,

Career adaptation,

Job adaptation,

Job adaptation

* Dr. Necmiye Tülin İRGE, İstanbul Aydın Üniversitesi, İktisadi ve İdari Bilimler Fakültesi, İşletme Bölümü, necmiyeirge@aydin.edu.tr, ORCID ID: https://orcid.org/0000-0001-9936-6229

** İbrahim YILDIRIM, İstanbul Aydın Üniversitesi, Lisansüstü Eğitim Enstitüsü, İşletme Yönetimi, ibrahimyildirim5@stu.aydin.edu.tr. ORCID ID: https://orcid.org/0000-0002-3283-1437

*** Hazem ASSALİ, İstanbul Aydın Üniversitesi, Lisansüstü Eğitim Enstitüsü, İşletme Yönetimi, hazemassali@stu.aydin.edu.tr, ORCID ID: https://orcid.org/0000-0002-7936-4848 


\section{GíRIŞ}

Günümüzde birçok işletme herhangi bir ürünü kolaylıkla üretebilmekte, dünyanın herhangi bir bölgesindeki pazarlara kolaylıkla ulaşabilmektedir. Üretimin gelişen teknolojilerle birlikte çok daha kolay olması nedeni ile rekabetin arttığı bu dönemde makinalar aynı olsa da tüm insanların farklı özellikleri olduğu göz önünde bulundurulduğunda örgütte çalışanların örgüte kattıkları artı değerler ile rekabet üstünlügü elde etmeleri konusu gündeme gelmiştir. İnsanlar sahip oldukları bireysel özellikteki farklı yetenekler, farklı üstünlükler ve farklı deneyimlerle bulundukları örgütleri diğer örgütlerden farklılaştırmaktadır. Rekabet avantajı sağlayacak bir diğer unsurda çalışanların bulunmuş oldukları örgütte kendilerini huzurlu ve mutlu hissetmeleri ve pozitif davranış sergilemeleridir. Çalışanların pozitif davranışlarının gelişimi amacı ile "pozitif örgütsel davranış” kavramı ortaya çıkmıştır.

Pozitif örgütsel davranışın ortaya attığı kavramlardan birisi de psikolojik sermayedir. Psikolojik sermaye kavramı günümüzde örgütler için kullanılan oldukça yeni bir sermaye türüdür. Beşeri ve sosyal sermaye uzun süredir örgütlerde yoğun bir şekilde kullanılan sermaye türleri olarak karşımızda yer alırken, psikolojik sermaye uygulamalarına yeni başlanılmıştır. Psikolojik sermaye içerisinde boyutlar çalışanların psikolojik kaynakları; umut, iyimserlik, öz yeterlilik, dayanıklı olmalarıdır. Psikolojik sermaye, bireyin sahip olduğu olumlu özellikler bütünü olarak tanımlanırken, kişilik özelliklerinden farklı olarak gelişime açık olduğu vurgulanmaktadır. Psikolojik sermaye; örgütlerin rekabet üstünlüğü sağlayabilmeleri için parasal sermayeden, beşeri sermaye ve sosyal sermayeden çok daha fazla önemli bir konuma gelmiştir. Psikolojik sermayenin önemini anlatan çalışmalarda, psikolojik sermayenin kişiye ve kuruma katkısı belirtilmektedir. Psikolojik sermaye bireylerin olumsuz ve hatalı yönlerine değinmek yerine bireyler için doğru olanın ne olduğuna ve hangisinin daha iyi olacağına odaklanmaktadır. Literatürde yapılan çalışmalarda psikolojik sermayenin iş tatmini, işe adanmışl1k, işe bağlılık, işle bütünleşme, stresle başa çıkabilme, işten ayrılma isteği, devamsızlık ve performans konuları ile ilişkili olduğu görülmüştür. Pozitif psikolojik sermaye ve örgütsel vatandaşlık davranışı arasında pozitif ilişki, örgütsel sinizm, işten ayrılma isteği ve üretken olmayan faaliyetler arasında negatif ilişki bulunmuştur.

Kariyer adaptasyonu kişinin iş yaşamında önceden tahmin edilebilen veya var olan görev tanımları ile daha önceden bilinemeyen değişikliklerin neden olduğu kararsızlık durumlarıyla mücadele edebilmesidir. Kariyer adaptasyonu mesleki görevlere ve mesleki hayatta karşılaşılan ve iş ile ilgili olan ve değişkenlik gösteren farklı sorunlara farklı çözüm yollarıyla uyum sağlanmasını içerir. Kötümserler bir hedefe ulaşma yolunda üzerlerine düşen görevleri yerine getirmede daha başarısız olabilmektedirler. Güçlü psikolojik sermayeye sahip olan geleceğe yönelik umut için de olan iyimser bir psikolojide olan, öz yeterliliği yüksek olan bireyler ise pozitif ve esnek düşünce yeteneğine sahip 
oldukları için değişen durumlara dahi iyi adapte olabilmektedir. Yapılan literatür taramasında psikolojik sermaye ve kariyer adaptasyonu kavramlarının başka değişkenlerle ilişkilerinin araştırıldığ 1 az sayıda çalışmaya rastlanmıştır. Bu araştırmaların bazıları aşağıda yer almaktadır.

\section{LITERATÜR TARAMASI}

$\mathrm{Bu}$ araştırmada incelenen psikolojik sermaye ve kariyer adaptasyonu değişkenleri ile yurtiçinde yapılan literatür taramasında az sayıda araştırma olduğu görülmüştür. Psikolojik sermaye ve kariyer adaptasyonu ile ilgili olarak öğrenciler üzerinde yapılan bir çalışmada öğrencilerin kariyer uyum yeteneği boyutları ile psikolojik sermaye boyutları arasında pozitif bir ilişki olduğu görülmektedir (Mercan, 2016). Kariyer adaptasyonu, yapılan bir çalışmada psikolojik sermaye, kariyer uyumu ve kariyer yeterliliği ile birlikte alınmıştır (Safavi ve Bouzari, 2019). Psikolojik sermaye ve kariyer adaptasyonu kavramlarının başka değişkenlerle ilişkilerinin araştırıldığı çalışmalardan birinde çalışanların örgütsel destek algılarının örgütsel vatandaşlık algılarına etkisi psikolojik sermaye ile ilişkilendirilmiştir. Örgütsel vatandaşlık vicdanlılık alt boyutu ile psikolojik sermaye alt boyutları olan öz yeterlik ve dayanıklık, umut ve iyimserlik alt boyutları arasında pozitif yönlü ve anlamlı bir ilişki olduğu, belirlenmiştir. Benzer şekilde vicdanlılık alt boyutu ile psikolojik sermaye ve örgütsel destek ölçeği toplam ölçek puanları arasında pozitif yönlü ve anlamlı bir ilişki olduğu belirlenmiştir (Demirci, 2018). Psikolojik sermeyenin ilişkili olduğu başka bir kavram ise işe adanmışlık kavramıdır. İse adanmışlıkla ilgili yapılan çalışmada psikolojik sermayenin işe adanmışlık ve kuruma adanmışlık üzerindeki etkileri desteklenmekte; böylece pozitif psikolojik sermayenin bireylerin işe dair tutum ve davranışlarını şekillendirmedeki rolünün altı çizilmektedir (Ertosun, 2016). Yapılan bir çalışmada kişisel değerler ile pozitif sermaye arasındaki ilişkinin iş tatmini üzerinde etkili olduğu belirlenmiştir (Akçay, 2011). Yapılan başka bir çalışmada dünyanın birçok noktasında farklılaşmaya çalışan işletmelerin çalışan katılımı sonucu işletmeye sağlayacakları üstün değerler ile farklılaşabileceği, psikolojik sermayenin de çalışan katılımında etkili olabileceği belirtilmektedir. Çalışmada psikolojik sermayenin çalışan katılımı ile birlikte toplam işletme performansını da olumlu anlamda etkileyebileceği belirtilmektedir (Levene, 2015). Bireyin psikolojik sermayesinin yüksek olması, sahip olduğu potansiyeli tam olarak kullanabilmesini sağlamaktadır. Böylece iş ve aile hayatı arasındaki etkileşimi kendi menfaatine göre yönetmesi, en önemlisi de performansının yükselmesi mümkün olmaktadır ( Zhao, and Hou, 2009). Psikolojik sermayenin, çalışanın stresle başa çıkması, iş tatmini ve örgütsel bağl1lığa etkisinin ortaya konduğu çalışmalar da bulunmaktadır. (Zağl1, 2016). Kriz yönetimi ve psikolojik sermaye arasındaki ilişkiyi saptamaya yönelik başka bir araştırmada araştırmaya katılan öğretmenlerin kriz yönetimine ilişkin görüşlerinin psikolojik sermayelerini etkilediği; kriz yönetimi konusunda okuluna yönelik olumlu görüş bildiren öğretmenlerin psikolojik 
sermayelerinin yüksek; kriz yönetimine ilişkin olumsuz görüş bildiren öğretmenlerin psikolojik sermayelerinin düşük olduğu sonucuna ulaşılmıştır (Şahin, 2014). Kariyer adaptasyonu açısından eski ve yeni okul yöneticilerinin değerlendirildiği (Cereci, 2019), kişilik özellikleri ve girişimcilik niyetlerinin kariyer adaptasyonu ile ilişkisinin araştırıldığı (İspir vd., 2019), kariyer esnekliği ve istihdam ile birlikte ele alındığı (Rochat vd, 2017) çalışmalar da gözlemlenmiştir.

Psikolojik sermayenin kariyer adaptasyonuna etkisi ile ilgili literatürde az sayıda çalışma bulunmaktadır. $\mathrm{Bu}$ çalışma ile literatüre katkı sağlanması amaçlanmaktadır. İşletmelerin insan kaynakları birimleri tarafından yapılan çalışan seçiminde adayda beklenen temel özelliklere güçlü psikolojik sermayeye sahip olma özelliğinin de eklenmesinin işletmelerde karşılaşılan sorunların etkin çözümü ve pazarın beklentisi olan yenilikçi ürün üretmek için gerekli olan örgüt iklimini oluşturmaya katkı sağlayacağı düşünülmektedir. Güçlü psikolojik sermayeye sahip olmanın yeni çalışan seçiminde bir kriter olmasının öneminin yanı sıra mevcut çalışanların psikolojik sermayelerinin güçlendirilmesinin de işletmelerdeki verimliliği artıracağı ve bunun sonucunda işletme karlılığını olumlu etkileyeceği düşünülmektedir. Bu çalışma yoğun rekabet ortamında bulunan işletmelere rekabet üstünlüğü sağlamaları için psikolojik sermaye faktöründen faydalanmalarını ve kariyer adaptasyonu süreçlerinde etkin olarak kullanılmasını sağlamayı amaçlamaktadır.

\section{KAVRAMSAL ÇERÇEVE}

\section{Psikolojik Sermaye}

Psikolojik sermaye: Çalışanı etkileyen ve kendisini umutlu hissettiren bir grup pozitif psikolojik duygudur (Asia, 2018: 16). Psikolojik sermaye son yıllarda dikkat çeken ve üzerinde çalışmalar yapılan güncel bir konu haline gelmiştir. Psikolojik sermaye ilk kez Fred Luthans ve arkadaşları tarafından ortaya konan ve bireylerin pozitif güçleri ile ilişkilendirilen bir kavramdır (Luthans, 2002: 57). Önceki birçok çalışmada üzerinde durulan ekonomik, beşeri ve sosyal sermaye türlerine nazaran psikolojik sermaye kavramı farklı özelliklere sahip bir sermaye türüdür. Psikolojik sermaye "bireyin pozitif psikolojik gelişme hali" olarak tanımlanmakla birlikte psikolojik sermayenin insanda "Ben kimim?” sorusunun cevabını aradığı ifade edilmektedir (Ertosun, 2016: 17). Psikolojik sermaye klasik sermaye faktörlerinden farklı olarak sen kimsin, hangi özelliklerin güçlüdür, hangi özelliklerin pozitif yönde geliştirilebilir?” sorularına cevap aramaya çalışır ve bunları geliştirmeyi hedefler (Erdem vd., 2015: 41). Psikolojik sermaye işletmelerin rekabet avantajı elde etmelerinde ekonomik, sosyal ve insan sermayesinden farklı olarak ön plana çıkan bir kavramdır (Şahin, 2014: 69). Psikolojik sermeye kişinin belirli bir sürede bilgi, deneyim, tecrübeleri ile oluşan bireysel farkındalığı ile ilişkilidir. Bu farkındalık bireyin özellikle iş yaşamında verimliliğe etki edebileceği belirtilmektedir. Psikolojik sermaye insanın sahip olduğu bu tecrübelerin pozitif yönde gelişimini sağlayarak kişinin sahip olduğu özelliklere artı 
değer katabileceği belirtilmektedir. Psikolojik sermayenin kişinin değişmesi zor olan durağan bireysel özelliklerinden farklı olarak geliştirilebilir olduğu vurgulanmaktadır (Erkuş A. ve Fındıklı M., 2013: 304).

\section{Psikolojik Sermaye Boyutları}

Psikolojik sermaye ile ilgili yapılan araştırmalar sonucunda psikolojik sermayeyi oluşturan dört pozitif unsurun bulunduğu ve bu unsurların psikolojik sermayeyi tanımladığı belirtilmektedir. Bu unsurlar aynı zamanda psikolojik sermayenin boyutlarını oluşturmaktadır (Zağlı, 2016: 30). Psikolojik sermayeyi bireyin, dört unsurla karakterize edilen pozitif psikolojik gelişim durumu olarak adlandırabileceğimiz "PsyCap" olarak tanımlayabiliriz (Luthans, 2007).

Umut psikolojik sermayenin önemli bileşenlerindendir. Bireylerin başarı bilincinden elde ettikleri olumlu motivasyon olarak tanımlanır. Umudu yüksek olan bireyler bağımsız düşünür olma eğilimindedir, risk alır ve sorunlar karşısında alternatif yollar ararlar (Saleh, 2016: 8). Yüksek umuda sahip olan kişilerin iş ve sosyal yaşamlarında karşılaştıkları problemlerin üstesinden gelip kendilerine, bulundukları topluma ve çalışmış oldukları işletmelere olumlu etkileri olduğu ve onları dinç tuttukları söylenebilir (Çetin vd., 2012: 123-124 ). Psikolojik sermayenin iyimserlik boyutu ile ilgili olarak pozitif bir bakış açısına sahip olan ve yaşamlarında karşılaştıkları olayları ve çevrelerinde olup bitenleri iyimser bakış açısı ile değerlendirebilen bireyler, iş ve sosyal yaşamlarında başkalarına oranla daha başarılı olmakta ve kendilerini genellikle daha enerjik ve mutlu hissetmektedirler (Akın vd., 2015: 266). Luthans (2007) öz yeterliği "kişinin kendini motive edebilme, bilişsel kaynakları ve verilen işi başarıyla yerine getirebilme konusundaki yeteneklerine olan inancı" şeklinde tanımlamıştır. Öz yeterlik, zorlu görevlerde başarılı olmak için gerekli mücadeleyi yapabilmek anlamına gelir. Dayanıklılık veya Esneklik, başarıya ulaşmak için sorunlardan ve sıkıntıdan kurtulma ve geri dönme yeteneği anlamına gelir. İyimserlik, şimdi ve gelecekte başarıya ulaşmada olumlu düşünebilme kapasitesidir. Umut hedeflere doğru 1srarlı bir şekilde ilerleme ve gerektiğinde başarılı olmak için yollar belirlemedir (Luthans, 2007). Dayanıklılık birçok negatif durumla karşılaşılmasına rağmen bireyin kendini negatif durum içine bırakmayıp başarı için ilerlemesidir (Erdem, 2015: 42).

\section{Kariyer Adaptasyonu}

Kariyer adaptasyonu mevcutta bulunan ve tahmin edilebilen görev tanımları ile iş yaşamlarında tahmin edilemeyen dinamik çevresel değişkenlerin oluşturduğu belirsizlik durumlarıyla mücadele edebilmesidir (Zorver, 2011: 39). Çeşitli kariyer geçişleri hedeflerimizi, tutumlarımızı ve mesleki rutinlerimizi yeniden değerlendirmemizi ve bu yüzden adaptasyon yeni işteki görevlere hazırlık ve çalışma için öngörülebilir ve öngörülemez görevlerle baş etmeye hazır olmayı gerektirmektedir (Savickas, 1997: 254). Adaptasyon, mesleki davranışı inceleyerek ortaya çıkan karmaşıklığı 
birleştirmek için köprüleyici bir yapı görevi görür. Kariyer adaptasyonu, kariyer gelişiminin perspektifindeki kritik yapı olarak yerini almalıdır. Adaptasyonun gelişimsel boyutları kariyer olgunluğuna benzemektedir, yani planlama, araştırma, keşfetme ve karar verme süreçleri adaptasyona dahildir (Savickas 1997: 247). Günümüzde yaşam boyu istihdam edilebilirlik birçok çalışanın merkezi sorunu haline gelmiştir. Kariyer adaptasyonun artırılmasının, bir kişinin çalıştığı organizasyondaki kariyerini başarılı bir şekilde yönetmek için gerekli temeli sağlayabileceği önerilmektedir (Taber, 2019: 103). Kariyerini planlayan çalışanlar için adaptasyonu gözlemlemek amaciyla ölçümler gerçekleştiren Nota ve diğerleri (2012: 1557) iş adaptasyonu ve kariyer adaptasyonunu birlikte değerlendirmektedir. Çalışanların iş yaşamlarını etkileyen koşullara uyum sağlaması ve kariyer yönetimini iyi yapabilmesi konusunda; güçlü yönleri, tüm bilgi ve kaynakları belirleyici olmaktadır (Rottingaus vd., 2011: 123).

\section{Kariyer Adaptasyonu Boyutları}

Kariyer adaptasyonu boyutlarından olan yeteneğe güven ve geleceğe iyi bakma benlik kavramı ile ilgilidir. Bireyin kendisi hakkındaki düşüncesi, onu nasıl gördüğü ve yeteneklerini nasıl gördüğü, değerlendirmesinin kapsamı ve gelecekteki görüşünün ne olacağı anlamına gelir. Bunların hepsi, kendine güveninin ana unsurlarıdır. Çünkü bireyin kendisi tecrübe kaynağıdır. Birey, bilişsel ve duygusal deneyimlerden oluşan davranışları sayesinde kendini kabul eder, bu da onun mesleğe kabule ve uyuma yaklaştırır (Al-Rawahia, 2016: 15). Bir diğer boyut olan öz kontrol ise istenmeyen davranışlardan kaçınmak, istenen davranışları arttırmak ve uzun vadeli hedeflere ulaşmak için cevapları düzenleme ve değiştirme yeteneği olarak tanımlanabilir (Rottingaus vd., 2009: 116). Kariyer adaptasyonunun diğer boyutu ise güvengen yetenekler ve sosyal sorumluluklardır. Grup içindeki bireylerin kendilerine verilen görevleri üstlenmeleri, iş, hizmet ve amaçlara ulaşmada katkıda bulunmaları ve gruba yönelik görevleri yerine getirmelerinin sosyal hizmet uzmanının denetimi, rehberliği ve takibi yoluyla onaylanması anlamına gelmektedir (Al-Rawahia, 2016;39). güvengen yetenekler başkalarını küçük görmeden, onların haklarını yadsımadan bireylerin kendi haklarını ve duygularını koruyabilmeleridir. Bir diğer alt boyut merak ve keşfetme boyutunda Merak, bilmek, görmek ve tecrübe edinmek adına bilgi edinme davranışımızı motive eden içsel bir istek olarak ifade edilmektedir (Litman, 2007: 149). Merak sistematik bilgiye götüren bilimsel bir yöntem olan bilgi ve eğitim arayışı ve farklı bilgiler elde etmedir. Keşif ise deneyim yolu ile bilgi edinmektir (Kafrouny, 2016: 36). Zaman algısı ve bireysel yükümlülük boyutu, zamanın farkına varılması, bireyin kendisine verilen görevlere, özellikle de işiyle ilgili görevlere ulaşma taahhüdünde bulunmasına yardımcı olan ve aynı zamanda bireyin başarısını takip etme ve kendi hedeflerine ve ustalığına ulaşma isteğini güçlendirmeye yardım eden temellerden biridir. $\mathrm{Bu}$, özellikle etkinlik, verimlilik veya üretkenliği 
arttırmak için belirli faaliyetlere harcanan zaman boyunca bilinçli kontrolün planlanması ve uygulanmasıyla yapılır (Feki, 2014: 23).

Bu çalışmada psikolojik sermayenin kariyer adaptasyonuna etkisi incelenerek, işletmelerde gerek işe alımlarda psikolojik sermayesi güçlü adayların tercih kriterlerinden olması gerekse mevcut çalışanın psikolojik sermayesini güçlendirerek kariyer adaptasyonu süreçlerinde etkin kullanılmasına katkı sağlanması amaçlanmıştır. Bu kapsamda ortaya konan araştırma modeli ve hipotezleri aşağıda sıralanmıştır.

\section{MATERYAL VE YÖNTEM}

Araştırmanın evrenini İstanbul ilinin Avrupa yakasında sıvı temizlik ürünleri üretimi yapan firmalarda farklı görevlerde çalışan kişiler oluşturmaktadır. Birçok kurumun açıkladığı istatistiklerde evren sayısına yönelik net bir bilgiye rastlanamadığı için, örneklemin yeterliliği konusunda Güç Analizi (Power Analysis) yapılmıştır. Güç analizi G*POWER 3.1 sürümü ile gerçekleştirilmiştir. Çalışmalarda, istatistiksel gücün 1- $\beta=0.80$ alınmasının yeterli olduğu Cohen (1988) ve Parajapati et al., (2010) çalışmalarında belirtilmiştir. Buna göre güç analizi sonucunda, 0.05 anlamlılık düzeyi için, ilişki analizleri 111 kişi ve grup farklılığı analizleri için 112 kişi olarak belirlenmiştir. Buna göre; istatistik olarak anlamlı ve yorumlanabilir ilişki sonuçları üretebilmek için en az 112 örnekleme ihtiyaç vardır. Güç analizi sonuçları Şekil ** da verilmiştir.

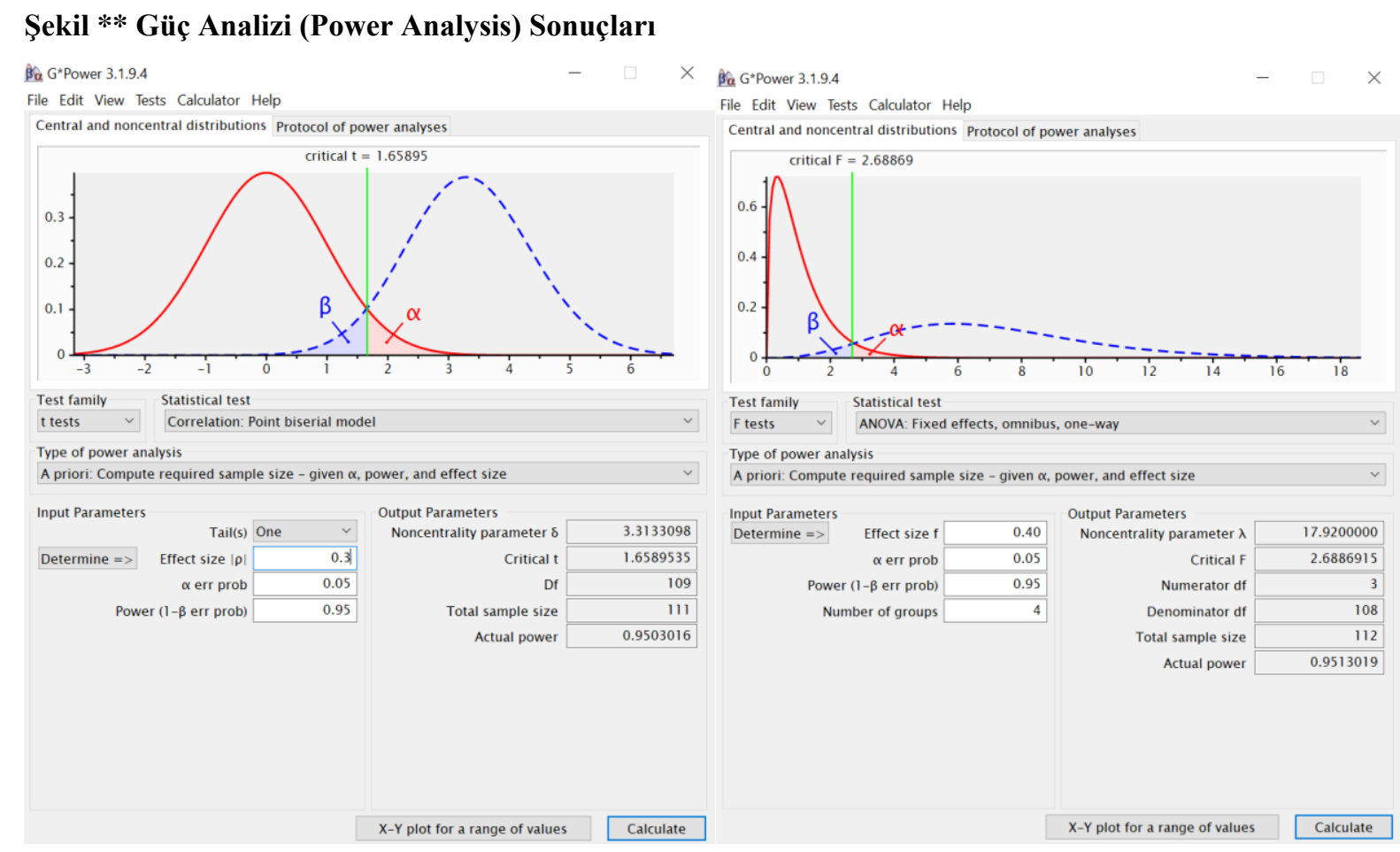

Örneklem olarak 2019 yılının Ekim-Aralık ayları arasında, İstanbul ilinde, kolayda örneklem yöntemi ile bu firmaların çalışanlarına anketler elden dağıtılarak ve dijital ortamda paylaşılarak ulaşılmıştır. 
136 çalışandan geri dönüş alınmış ancak 14 anket eksik ve/ya hatalı olduklarından çıkarılarak toplam olarak 122 anket değerlendirilmeye alınmıştır.

Araştırmada kullanılan ve 24 sorudan oluşan psikolojik sermaye ölçeği Luthans ve arkadaşları tarafından 2007 yılında geliştirilmiş ve Davut Demirci’nin Çalışanların Örgütsel Destek Algılarının Örgütsel Vatandaşlık Davranışlarına Etkileri; Psikolojik Sermayenin Bu Süreçteki Rolü ve bir Araştırma adlı doktora tezinden alınmıştır. Araştırmada kullanılan Nota, Ginevra ve Soresi tarafından 2012 yılında geliştirilen, 31 sorudan oluşan Kariyer ve iş adaptasyonu ölçeği ise, Çınar Kaya, Ahmet Akın, Hakan Sarıçam ve Erol Uğur'un Turkish Version of Career And Work Adaptability Quastionna (CWAQ): Validty and Reliability Study adlı çalışmalarından alınmıştır. Anketler 2020 öncesi toplandığı için ayrıca anket etik izni alınmamıştır.

Araştırmanın hipotezleri şu şekildedir:

$\mathrm{H}_{1}$ : Psikolojik sermaye ve kariyer ve iş adaptasyonu arasında istatistik anlamlı ilişki vardır.

$\mathrm{H}_{1 \mathrm{a}}$ : Psikolojik sermaye alt boyutları ile kariyer ve iş adaptasyonu alt boyutları arasında istatistik anlamlı ilişki vardır.

Araştırmanın modeli ise aşağıda gösterilmektedir:

\section{Şekil 1. Araştırmanın Modeli}

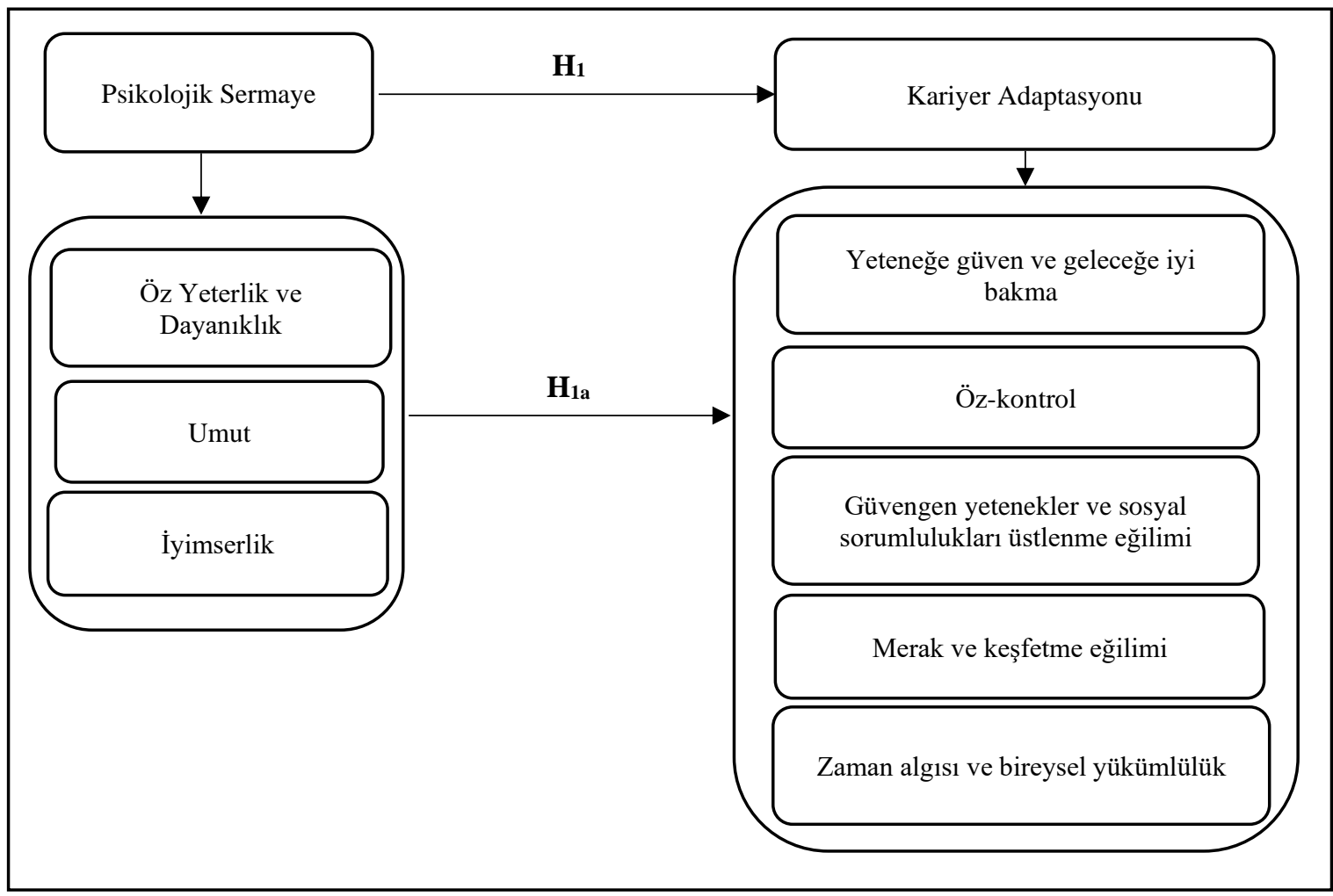




\section{BULGULAR}

\section{Demografik Özelliklerin Dağılımları}

Bu bölümde çalışanların cinsiyet, yaş, eğitim düzeyi, işyerindeki pozisyon, işyerindeki çalışma süresi ve toplam iş tecrübesinin frekans ve yüzde dağılımlarına yer verilmekte ve elde edilen sonuçlar değerlendirilmektedir.

\section{Çizelge 1. Demografik Dă̆glım}

\begin{tabular}{llcc}
\hline & & Sayı (n) & Yüzde (\%) \\
\hline \multirow{3}{*}{ Cinsiyet } & Erkek & 88 & 72,1 \\
& Kadın & 34 & 27,9 \\
& Toplam & 122 & 100,0 \\
Medeni Durum & Bekar & 62 & 50,8 \\
& Evli & 60 & 49,2 \\
Taş & Toplam & 122 & 100,0 \\
& $18-24$ yaş & 34 & 27,9 \\
Eğitim Durumu & 25 yaş ve üstü & 88 & 72,1 \\
& Toplam & 122 & 100,0 \\
İşletmedeki Çalışma Süresi & Lisögretim & 48 & 39,3 \\
& Önlisans, Lisans ve Lisansüstü & 40 & 32,8 \\
Toplam Çalışma Süresi & Toplam & 34 & 27,9 \\
& 1 yıldan az & 122 & 100,0 \\
Çalıştığı Pozisyon & 1 yıl ve üstü & 65 & 53,3 \\
& Toplam & 57 & 46,7 \\
Gelir Düzeyi & 5 yıl ve altı & 122 & 100,0 \\
& 6 yıl ve üstü & 54 & 44,3 \\
\hline
\end{tabular}

Çalışanların \%72,1'i erkek iken \%27,9'u kadın, \%50,8'î bekar ve \%49,2'si evlidir. Bu kişilerin yaş dağılımlarına bakıldığında, \%27,9’u 18-24 yaş arasında, \%72,1'i 25 yaş ve üstüdür. Eğitim düzeyi dağılımı için değerlendirme şu şekilde olmaktadır. Çalışanların \%39,3'ü ilköğretim mezunu, \%32,8’i lise mezunu, \%27,9’u önlisans, lisans ve lisansüstü mezunudur. Araştırmaya katılanların \%53,3’ü 1 yıldan az süredir firmada çalışmaktadır, \%46,7'si 1 yıl ve üstü süredir firmada çalışmaktadır. Çalışan kişilerin \%44,3’ü 5 yıl ve altı, \%55,7'si 6 yıl ve üstü toplam çalışma tecrübesine sahiptir. Çalışanların \%25,4'ü beyaz yaka, \%74,6’sı mavi yakadır. Çalışanların 73,0’1 2020-2500 TL arasında, \%27,0’1 2501 TL ve üstü gelire sahiptir.

\section{Açıklayıcı Faktör Analizi ve Güvenirlik Analizine İlişkin Bulgular}

$\mathrm{Bu}$ çalışmada çalışanlara uygulanan psikolojik sermaye ile kariyer ve iş adaptasyonu ölçeklerinin geçerliğini ve güvenirliğini tespit etmek için açıklayıcı faktör analizi ile güvenilirlik analizi gerçekleştirilmektedir. Toplam 24 maddeden oluşan psikolojik sermaye ölçeği için yapılan açıklayıcı 
faktör analizi sonucunda 0,50'nin altında bulunan, birden fazla faktör yükü olan ve farklı faktör yapısının içinde bulunan on üç madde sırayla analiz dışında bırakılarak açıklayıcı faktör analizi yapılmaktadır (Kalaycı, 2008: 329). Bu sonuçlara göre, ölçeği oluşturan alt faktörlerden öz yeterlilik boyutu ile dayanıklılık alt boyutu aynı faktör içinde oluştuğu belirlenmiştir. Her bir faktördeki ifadeler güvenirlik analizi yapıldıktan sonra iyimserlik alt boyutu içindeki 11. ve 19. ifadelerin iç tutarlılık katsayıları düşük çıktığı için analize dahil edilmeden faktör analizi tekrardan yapılmaktadır. Psikolojik sermaye ölçeği toplam iki faktör altında toplanan madde ile yapılmaktadır. Analiz dışı bırakılan sorular $1,3,4,6,8,9,11,12,14,16,18,19,21,22$ ve 24. sorulardır. Psikolojik sermaye ölçeği, Luthans ve arkadaşları (2007) tarafından iyimserlik, psikolojik dayanıklık, umut ve özyeterlik olmak üzere dört boyut olarak geliştirilmiştir. $\mathrm{Bu}$ çalışmada ise tabloda görüldüğü üzere yapılan faktör analizi sonucunda özyeterlik ve dayanıklık boyutları tek bir faktör olarak belirlenmiştir ve tek faktör olarak değerlendirilmiştir.

\section{Çizelge 2. Psikolojik Sermaye Ölçeği Açıklayıcı Faktör Analizi ve Güvenirlik Analizi Sonuçları}

\begin{tabular}{|c|c|c|c|c|c|}
\hline & & Faktör Yükü & Varyans Yüzdesi & Cronbach Alfa & $n$ \\
\hline \multirow{6}{*}{$\begin{array}{l}\text { Özyeterlik ve } \\
\text { Dayanıklık }\end{array}$} & 13. İşimde birçok şeyi halledebileceğimi hissediyorum. & 0,766 & \multirow{6}{*}{32,223} & \multirow{6}{*}{0,886} & \multirow{6}{*}{6} \\
\hline & $\begin{array}{l}\text { 7. Genellikle, işimdeki stresli şeyleri sakin bir şekilde } \\
\text { hallederim. }\end{array}$ & 0,765 & & & \\
\hline & $\begin{array}{l}\text { 15. Yöneticilerime işimle ilgili konuları açıklarken } \\
\text { kendime güvenirim. }\end{array}$ & 0,695 & & & \\
\hline & $\begin{array}{l}\text { 23. Kurum dışındaki kişilerle (Veliler veya çevremdeki } \\
\text { diğerleri) problemleri tartışmak için temas kurarken } \\
\text { kendime güvenirim. }\end{array}$ & 0,686 & & & \\
\hline & 10. Eğer zorunda kalırsam, işimde kendi başıma yeterim. & 0,639 & & & \\
\hline & $\begin{array}{l}\text { 5. Daha önceleri zorluklar yaşadığım için, işimdeki zor } \\
\text { zamanların üstesinden gelebilirim. }\end{array}$ & 0,628 & & & \\
\hline \multirow{2}{*}{ Umut } & $\begin{array}{l}\text { 20. Şu anda iş amaçlarımı sıkı bir şekilde takip } \\
\text { ediyorum. }\end{array}$ & 0,697 & \multirow{2}{*}{21,798} & \multirow{2}{*}{0,809} & \multirow{2}{*}{2} \\
\hline & $\begin{array}{l}\text { 17. Şu anda, işimde kendimi çok başarılı olarak } \\
\text { görüyorum. }\end{array}$ & 0,688 & & & \\
\hline
\end{tabular}

Çizelge 2'de görüldüğü üzere KMO testi \%89,5'dir. \%89,5>0,50 olduğu için veri seti faktör analizi için uygun olduğu söylenebilir. İkinci olarak bakılan test ise Bartlett testidir. Yapılan analiz sonucunda bu testinde anlamlı olduğu sonucuna varıldı $(p=0,000<0,01)$. Bu sonuç boyutlar arasındaki yüksek korelasyonun varlığını ortaya koymaktadır. Yani veri seti faktör analizi için uygundur. Güvenirlik analizi sonucunda elde edilen genel Cronbach alfa katsayısı 0,910 olarak tespit edilmektedir. Psikolojik sermaye ölçeğinin toplam varyans yüzdesi de 64,129 'dur. Bu sonuç ölçeğin yüksek olduğunu göstermektedir. Birinci faktör özyeterlik ve dayanıklık faktörü olarak adlandırılmaktadır. Bu faktörün faktör yükleri 0,766-0,628 arasında değişmektedir ve varyans yüzdesi de 32,223'dür. Cronbach alfa katsayısı da 0,886 olarak tespit edilmektedir. Bu katsayı bu alt boyutun ifadelerinin iç tutarlılığının yüksek güvenirlikte olduğunu göstermektedir. İkinci faktör ise umut faktörü olarak 
isimlendirilmektedir ve faktör yükleri 0,697-0688 arasında değişmektedir. Varyans yüzdesi de 21,798'dir. Tüm faktörler varyansın \%54,0’’nı (54,021) açıklamaktadır.

Toplam 31 maddeden oluşan kariyer ve iş adaptasyonu ölçeği için yapılan açıklayıcı faktör analizi sonucunda birden fazla faktör yükü olan ve farklı faktör yapısının içinde bulunan on dört madde analiz dışında bırakılarak açıklayıcı faktör analizi yapılmaktadır. Kariyer ve iş adaptasyon ölçeği toplam dört faktör altında toplanan madde ile yapılmaktadır. Analiz dışı bırakılan sorular $1,2,3,4,12,13,14,15,21,22,23,24,25$ ve 31 . sorulardır. Kariyer ve iş adaptasyonu ölçeğini aldığımız çalışmada elde edilen faktörler ile aynıdır.

Çizelge 3. Kariyer ve İş Adaptasyonu Ölçeği Açıklayıcı Faktör Analizi ve Güvenirlik Analizi Sonuçları

\begin{tabular}{|c|c|c|c|c|c|}
\hline & & $\begin{array}{l}\text { Faktör } \\
\text { Yükleri }\end{array}$ & $\begin{array}{l}\text { Varyans } \\
\text { Yüzdesi }\end{array}$ & $\begin{array}{l}\text { Cronbach } \\
\text { Alfa }\end{array}$ & $n$ \\
\hline \multirow{5}{*}{$\begin{array}{l}\text { Güvengen Yetenekler ve } \\
\text { Sosyal Sorumlukları } \\
\text { Üstlenme Eğilimi }\end{array}$} & 17. Ortak çalışmalarda kendi sorumluluğumu alabilirim. & 0,822 & \multirow{5}{*}{23,795} & \multirow{5}{*}{0,933} & \multirow{5}{*}{5} \\
\hline & 19. Aile içinde ya da bir çalışmada sorumlulukları üstlenebilirim. & 0,822 & & & \\
\hline & 18. İnanç ve ideallerime göre davranırım. & 0,784 & & & \\
\hline & $\begin{array}{l}\text { 16. İşbirliği yapar ve üzerime düşeni yapmakta tereddüt etmeden yerine } \\
\text { getirebilirim. }\end{array}$ & 0,749 & & & \\
\hline & 20. Başkalarının haklarıma saygı duymasını sağlayabilirim. & 0,727 & & & \\
\hline \multirow{5}{*}{$\begin{array}{l}\text { Zaman Algısı ve Bireysel } \\
\text { Yükümlülük }\end{array}$} & 27. Olabildiğince geleceğimle yüzleşmeye kendimi hazırlıyorum & 0,767 & \multirow{5}{*}{21,550} & \multirow{5}{*}{0,926} & \multirow{5}{*}{5} \\
\hline & 29. Gelecekle ilgili düşünür ve geleceği tahmin etmeye çalışırım. & 0,765 & & & \\
\hline & 28. Okumak ve bilgimi ve donanımı geliştirmekten hoşlanırım. & 0,764 & & & \\
\hline & $\begin{array}{l}\text { 30. Geleceğimin şu anda yaptıklarıma ve gelecekte yapacaklarımı bağlı } \\
\text { olduğuna düşünüyorum. }\end{array}$ & 0,741 & & & \\
\hline & $\begin{array}{l}\text { 26. Gelecekte çalışmayı ve kendimi güncellemeyi sürdürmek zorunda } \\
\text { olduğumu düşünüyorum. }\end{array}$ & 0,672 & & & \\
\hline \multirow{4}{*}{$\begin{array}{l}\text { Yeteneğe Güven ve } \\
\text { Geleceğe İyi Bakma }\end{array}$} & $\begin{array}{l}\text { 6. Geleceğimi düşündüğümde kendime olmak istediğim yerde olacağım } \\
\text { diyorum. }\end{array}$ & 0,857 & \multirow{4}{*}{18,295} & \multirow{4}{*}{0,873} & \multirow{4}{*}{4} \\
\hline & $\begin{array}{l}\text { 7. İşler yolunda gitmediğinde, pes etmeme ve zaman ve enerjimi uygun } \\
\text { harcama konusundaki yeteneğime güveniyorum. }\end{array}$ & 0,764 & & & \\
\hline & $\begin{array}{l}\text { 5. Fırsatları yakalama ve onlardan faydalanma konusundaki yeteneğime } \\
\text { güveniyorum. }\end{array}$ & 0,758 & & & \\
\hline & $\begin{array}{l}\text { 8. Seçtiğim mesleği en iyi şekilde yapmam için gerekenleri öğrenme } \\
\text { konusundaki yeteneğime güveniyorum. }\end{array}$ & 0,553 & & & \\
\hline \multirow{3}{*}{ Öz Kontrol } & 10. Sinirlerimi kontrol edebilirim & 0,888 & \multirow{3}{*}{15,839} & \multirow{3}{*}{0,906} & \\
\hline & 11. Sabırlı ve 1srarcı olabilirim. & 0,830 & & & 3 \\
\hline & 9. Provokasyonlara karşı direnç gösterebilirim. & 0,761 & & & \\
\hline
\end{tabular}

Çizelge 3'de görüldüğü üzere KMO testi \%89,3'dir. \%89,3>0,50 olduğu için veri seti faktör analizi için uygun olduğu söylenebilir. Bartlett testi sonucuna göre test anlamlıdır $(p=0,000<0,01)$. Yani veri seti faktör analizi için uygundur. Güvenilirlik analizi sonucunda elde edilen genel Cronbach alfa katsayısı 0,953 olarak tespit edilmektedir. $\mathrm{Bu}$ sonuç ölçeğin yüksek güvenilirlikte olduğunu göstermektedir.

İlk faktör olan güvengen yetenekler ve sosyal sorumlulukları üstlenme eğilimi faktörüdür, faktör yükleri 0,822-0,727 arasında değişmektedir ve varyans yüzdesi de 23,795'dir. Bu boyutun Cronbach alfa katsayısı 0,933 ile yüksek güvenilirdir. İkinci faktör zaman algısı ve bireysel yükümlülük faktörüdür, faktör yükleri 0,767-0,672 arasında değişmektedir ve varyans yüzdesi de 21,550'dir. Bu boyutun Cronbach alfa katsayısı 0,7926 ile yüksek güvenilirdir. Üçüncü faktör yeteneğe güven ve 
geleceğe iyi bakma faktörüdür, faktör yükleri 0,857-0,553 arasında değişmektedir ve varyans yüzdesi 18,295'dir. Bu boyutun Cronbach alfa katsayısı 0,873 ile yüksek güvenilirdir. Dördüncü faktör öz kontrol faktörüdür, faktör yükleri 0,888-0,761 arasında değişmektedir, varyans yüzdesi de 15,839'dur. Bu boyutun da Cronbach alfa katsayısı 0,953 ile yüksek güvenilirdir. Tüm faktörler toplam varyansın \%78,2'ini $(78,182)$ açıklamaktadır.

\section{Ortalama, Standart Sapma, Çarpıklık ve Basıklık}

Değişkenlerin ortalama ve standart sapmaları ile normal dağılıma uygunluğunun tespiti için çarpıklık ve basıklık değerlerine çizelge 4'de yer verilmektedir.

Çizelge 4. Değişkenlerin Ortalama, Standart Sapma, Basıklık ve Çarpıklık Değerleri

\begin{tabular}{|c|c|c|c|c|c|c|}
\hline & \multirow{2}{*}{$\bar{X}$} & \multirow{2}{*}{ SS } & \multicolumn{2}{|c|}{ Çarpıklık } & \multicolumn{2}{|c|}{ Basıklık } \\
\hline & & & İstatistik & $\varepsilon_{s_{h}}$ & İstatistik & $\varepsilon_{S_{h}}$ \\
\hline Psikolojik Sermaye & 4,13 & 0,744 & $-1,000$ & 0,219 & 0,580 & 0,435 \\
\hline Öz Yeterlilik ve Dayanıklılık & 4,13 & 0,777 & $-1,074$ & 0,219 & 0,824 & 0,435 \\
\hline Umut & 4,21 & 0,799 & $-0,943$ & 0,219 & 0,456 & 0,435 \\
\hline Kariyer ve İş Adaptasyonu & 4,21 & 0,632 & $-0,885$ & 0,219 & 0,134 & 0,435 \\
\hline Güvengen Yetenekler ve Sosyal Sorumlukları Üstlenme Eğilimi & 4,44 & 0,519 & $-0,640$ & 0,219 & $-0,154$ & 0,435 \\
\hline Zaman Algısı ve Bireysel Yükümlülük & 4,29 & 0,717 & $-0,898$ & 0,219 & 0,107 & 0,435 \\
\hline Yeteneğe Güven ve Geleceğe İyi Bakma & 4,20 & 0,680 & $-0,699$ & 0,219 & 0,143 & 0,435 \\
\hline Öz Kontrol & 4,06 & 0,813 & $-0,707$ & 0,219 & 0,219 & 0,435 \\
\hline
\end{tabular}

Psikolojik sermaye değişkeni ortalama değeri $4,13 \pm 0,744$, öz yeterlilik ve dayanıklılık faktörü

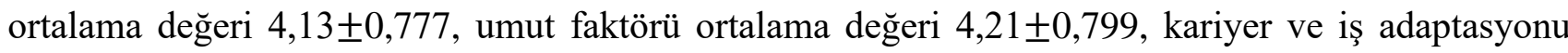
değişkeni ortalama değeri 4,21 $\pm 0,632$, güvengen yetenekler ve sosyal sorumlulukları üstlenme eğilimi

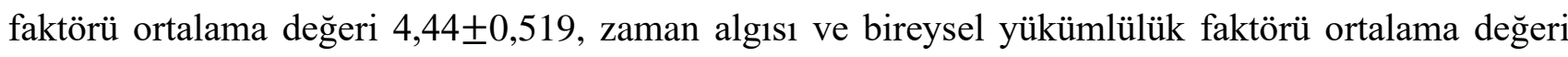
$4,29 \pm 0,717$ ve yeteneğe güven ve geleceğe iyi bakma faktörü ortalama değeri 4,20 $\pm 0,680$, öz kontrol faktörü ortalama değeri 4,06 $\pm 0,813$ olarak belirlendi. Tüm bu değişken ve faktörlerin basıklık ve çarpıklık değerleri $\pm 1,5$ aralığında yer aldığı için normal dağılıma yakındır (Kalaycı, 2008: 6). Bu sonuç fark testlerinde uygun olan parametrik testler kullanılması gerektiğini vermektedir.

\section{Fark Testleri}

Psikolojik sermaye ve boyutları, kariyer ve iş adaptasyonu ve boyutlarının cinsiyet, medeni durum, yaş, eğitim düzeyi, işyerindeki pozisyon, işyerindeki çalışma süresi, toplam iş tecrübesi ve gelir düzeyine göre anlamlılığı Bağımsız Grup T testi ve Tek Yönlü Varyans (ANOVA) analizi yapılarak tespit edilmektedir. 
Çizelge 5. Cinsiyete Göre Değişkenlerin Farklılığı

\begin{tabular}{|c|c|c|c|c|c|c|}
\hline & Cinsiyet & $n$ & $\bar{X}$ & $S S$ & $t$ & $p$ \\
\hline \multirow{2}{*}{ Psikolojik Sermaye } & Erkek & 88 & 4,08 & 0,737 & \multirow{2}{*}{$-1,341$} & \multirow{2}{*}{0,182} \\
\hline & Kadın & 34 & 4,28 & 0,755 & & \\
\hline \multirow{2}{*}{ Öz Yeterlilik ve Dayanıklık } & Erkek & 88 & 4,07 & 0,771 & \multirow{2}{*}{$-1,223$} & \multirow{2}{*}{0,224} \\
\hline & Kadın & 34 & 4,26 & 0,786 & & \\
\hline \multirow{2}{*}{ Umut } & Erkek & 88 & 4,16 & 0,811 & \multirow{2}{*}{$-0,994$} & \multirow{2}{*}{0,322} \\
\hline & Kadın & 34 & 4,32 & 0,768 & & \\
\hline \multirow{2}{*}{ Kariyer ve İş Adaptasyonu } & Erkek & 88 & 4,14 & 0,687 & \multirow{2}{*}{$-2,351$} & \multirow{2}{*}{$\mathbf{0 , 0 2 1}$} \\
\hline & Kadın & 34 & 4,38 & 0,421 & & \\
\hline \multirow{2}{*}{ Güvengen Yetenekler ve Sosyal Sorumlukları Üstlenme Eğilimi } & Erkek & 88 & 4,40 & 0,544 & \multirow{2}{*}{$-1,472$} & \multirow{2}{*}{0,144} \\
\hline & Kadın & 34 & 4,55 & 0,435 & & \\
\hline \multirow{2}{*}{ Zaman Algısı ve Bireysel Yükümlülük } & Erkek & 88 & 4,23 & 0,771 & \multirow{2}{*}{$-1,585$} & \multirow{2}{*}{0,117} \\
\hline & Kadın & 34 & 4,43 & 0,535 & & \\
\hline \multirow{2}{*}{ Yeteneğe Güven ve Geleceğe İyi Bakma } & Erkek & 88 & 4,17 & 0,735 & \multirow{2}{*}{$-0,975$} & \multirow{2}{*}{0,332} \\
\hline & Kadın & 34 & 4,29 & 0,512 & & \\
\hline \multirow{2}{*}{ Öz Kontrol } & Erkek & 88 & 4,03 & 0,844 & \multirow{2}{*}{$-0,670$} & \multirow{2}{*}{0,478} \\
\hline & Kadın & 34 & 4,14 & 0,735 & & \\
\hline
\end{tabular}

Bağımsız Grup T Testi sonucunda, cinsiyete göre psikolojik sermaye değişkeni, öz yeterlilik ve dayanıklılık ve umut, güvengen yetenekler ve sosyal sorumlulukları üstlenme eğilimi, zaman algısı ve bireysel yükümlülük, yeteneğe güven ve geleceğe iyi bakma ve öz kontrol faktörleri ortalama puanları arasında istatistiksel açıdan anlamlı bir farklılık tespit edilemedi ( $\mathrm{p} \geq 0,05)$. Cinsiyete göre kariyer ve iş adaptasyonu değişkeni ortalama puanları arasında anlamlı bir farklılığa rastlanmaktadır $(\mathrm{p}=0,021 \leq 0,05)$. Ortalama değerlere bakıldığında kadın çalışanların kariyer ve iş adaptasyonları erkek çalışanlara nazaran daha hızlı olmaktadır.

\section{Çizelge 6. Medeni Duruma Göre Değişkenlerin Farklılığı}

\begin{tabular}{|c|c|c|c|c|c|c|}
\hline & Medeni Durum & $n$ & $\bar{X}$ & $S S$ & $t$ & $p$ \\
\hline \multirow{2}{*}{ Psikolojik Sermaye } & Bekar & 62 & 4,09 & 0,783 & \multirow{2}{*}{$-0,731$} & \multirow{2}{*}{0,466} \\
\hline & Evli & 60 & 4,18 & 0,705 & & \\
\hline \multirow{2}{*}{ Öz Yeterlilik ve Dayanıklık } & Bekar & 62 & 4,12 & 0,820 & \multirow{2}{*}{$-0,146$} & \multirow{2}{*}{0,885} \\
\hline & Evli & 60 & 4,14 & 0,736 & & \\
\hline \multirow{2}{*}{ Umut } & Bekar & 62 & 4,04 & 0,860 & \multirow{2}{*}{$-2,357$} & \multirow{2}{*}{$\mathbf{0 , 0 2 0}$} \\
\hline & Evli & 60 & 4,38 & 0,697 & & \\
\hline \multirow{2}{*}{ Kariyer ve İş Adaptasyonu } & Bekar & 62 & 4,08 & 0,698 & \multirow{2}{*}{$-2,334$} & \multirow{2}{*}{$\mathbf{0 , 0 2 1}$} \\
\hline & Evli & 60 & 4,34 & 0,530 & & \\
\hline \multirow{2}{*}{ Güvengen Yetenekler ve Sosyal Sorumlukları Üstlenme Eğilimi } & Bekar & 62 & 4,39 & 0,553 & \multirow{2}{*}{$-1,236$} & \multirow{2}{*}{0,219} \\
\hline & Evli & 60 & 4,50 & 0,478 & & \\
\hline \multirow{2}{*}{ Zaman Algısı ve Bireysel Yükümlülük } & Bekar & 62 & 4,18 & 0,793 & \multirow{2}{*}{$-1,795$} & \multirow{2}{*}{0,075} \\
\hline & Evli & 60 & 4,41 & 0,613 & & \\
\hline \multirow{2}{*}{ Yeteneğe Güven ve Geleceğe İyi Bakma } & Bekar & 62 & 4,12 & 0,669 & \multirow{2}{*}{$-1,425$} & \multirow{2}{*}{0,157} \\
\hline & Evli & 60 & 4,29 & 0,685 & & \\
\hline \multirow{2}{*}{ Öz Kontrol } & Bekar & 62 & 3,92 & 0,844 & \multirow{2}{*}{$-1,895$} & \multirow{2}{*}{0,061} \\
\hline & Evli & 60 & 4,20 & 0,763 & & \\
\hline
\end{tabular}

Bağımsız Grup T Testi sonucunda, cinsiyete göre psikolojik sermaye değişkeni, öz yeterlilik ve dayanıklık, güvengen yetenekler ve sosyal sorumlulukları üstlenme eğilimi, zaman algısı ve bireysel yükümlülük, yeteneğe güven ve geleceğe iyi bakma ve öz kontrol faktörleri ortalama puanları arasında istatistiksel açıdan anlamlı bir farklılık tespit edilemedi $(p \geq 0,05)$. Cinsiyete göre kariyer ve iş adaptasyonu değişkeni $(p=0,021 \leq 0,05)$ ve umut faktörü $(p=0,020 \leq 0,05)$ ortalama puanları arasında anlamlı bir farklılığa rastlanmaktadır Ortalama değerlere bakıldığında evli çalışanların kariyer ve iş adaptasyonları bekar çalışanlara nazaran daha hızlı olmaktadır ve evli çalışanların umutları bekar çalışanlara göre daha yüksektir. 


\begin{tabular}{|c|c|c|c|c|c|c|c|c|}
\hline & & \multirow[b]{2}{*}{$n$} & \multirow{2}{*}{$\bar{X}$} & \multirow{2}{*}{$S S$} & \multicolumn{2}{|c|}{ Homojenliğin Levene Testi } & \multicolumn{2}{|c|}{ ANOVA } \\
\hline & & & & & Levene İstatistiği & $p$ & $F$ & $p$ \\
\hline \multirow{4}{*}{ Psikolojik Sözleşme } & İlköğretim & 48 & 4,14 & 0,829 & \multirow{4}{*}{1,597} & \multirow{4}{*}{0,207} & \multirow{4}{*}{0,168} & \multirow{4}{*}{0,846} \\
\hline & Lise & 40 & 4,09 & 0,689 & & & & \\
\hline & Önlisans, Lisans ve Lisansüstü & 34 & 4,19 & 0,696 & & & & \\
\hline & Toplam & 122 & 4,13 & 0,744 & & & & \\
\hline \multirow{4}{*}{ Öz Yeterlilik ve Dayanıklılık } & İlköğretim & 48 & 4,12 & 0,829 & \multirow{4}{*}{0,750} & \multirow{4}{*}{0,475} & \multirow{4}{*}{0,354} & \multirow{4}{*}{0,702} \\
\hline & Lise & 40 & 4,06 & 0,780 & & & & \\
\hline & Önlisans, Lisans ve Lisansüstü & 34 & 4,22 & 0,708 & & & & \\
\hline & Toplam & 122 & 4,13 & 0,777 & & & & \\
\hline \multirow{4}{*}{ Umut } & İlköğretim & 48 & 4,33 & 0,846 & \multirow{4}{*}{0,120} & \multirow{4}{*}{0,887} & \multirow{4}{*}{0,928} & \multirow{4}{*}{0,398} \\
\hline & Lise & 40 & 4,15 & 0,777 & & & & \\
\hline & Önlisans, Lisans ve Lisansüstü & 34 & 4,10 & 0,757 & & & & \\
\hline & Toplam & 122 & 4,21 & 0,799 & & & & \\
\hline \multirow{4}{*}{ Kariyer ve İş Adaptasyonu } & İlköğretim & 48 & 4,24 & 0,692 & \multirow{4}{*}{3,428} & \multirow{4}{*}{0,036} & \multirow{4}{*}{1,607} & \multirow{4}{*}{0,205} \\
\hline & Lise & 40 & 4,07 & 0,678 & & & & \\
\hline & Önlisans, Lisans ve Lisansüstü & 34 & 4,32 & 0,449 & & & & \\
\hline & Toplam & 122 & 4,21 & 0,632 & & & & \\
\hline \multirow{4}{*}{$\begin{array}{l}\text { Güvengen Yetenekler ve } \\
\text { Sosyal Sorumlukları } \\
\text { Üstlenme Eğilimi }\end{array}$} & İlköğretim & 48 & 4,42 & 0,564 & \multirow{4}{*}{1,481} & \multirow{4}{*}{0,232} & & \\
\hline & Lise & 40 & 4,41 & 0,528 & & & & \\
\hline & Önlisans, Lisans ve Lisansüstü & 34 & 4,51 & 0,444 & & & 0,409 & 0,665 \\
\hline & Toplam & 122 & 4,44 & 0,519 & & & & \\
\hline & İlköğretim & 48 & 4,30 & 0,750 & & & & \\
\hline Zaman Alg1s1 ve Bireysel & Lise & 40 & 4,19 & 0,803 & & & & \\
\hline Yükümlülük & Önlisans, Lisans ve Lisansüstü & 34 & 4,39 & 0,546 & 2,959 & 0,056 & 0,686 & 0,506 \\
\hline & Toplam & 122 & 4,29 & 0,717 & & & & \\
\hline & İlköğretim & 48 & 4,31 & 0,708 & & & & \\
\hline Yeteneğe Güven ve Geleceğe & Lise & 40 & 4,08 & 0,751 & 0075 & 0120 & 1278 & (1) \\
\hline İyi Bakma & Önlisans, Lisans ve Lisansüstü & 34 & 4,20 & 0,529 & $2,0 / 5$ & 0,130 & $1,2 / 6$ & 0,283 \\
\hline & Toplam & 122 & 4,20 & 0,680 & & & & \\
\hline & İlköğretim & 48 & 4,26 & 0,842 & & & & \\
\hline$\ddot{O}_{z}$ Kontrol & Lise & 40 & 3,80 & 0,866 & 100 & 0115 & 3777 & 0026 \\
\hline Uz Kontrol & Önlisans, Lisans ve Lisansüstü & 34 & 4,08 & 0,620 & 2,199 & 0,115 & 3,777 & 0,026 \\
\hline & Toplam & 122 & 4,06 & 0,813 & & & & \\
\hline
\end{tabular}

ANOVA testi sonucunda eğitim düzeyine göre psikolojik sermaye değişkeni, öz yeterlilik ve dayanıklık ve umut faktörü ile kariyer ve iş adaptasyonu değişkeni, güvengen yetenekler ve sosyal sorumlulukları üstlenme eğilimi, zaman algısı ve bireysel yükümlülük ile yeteneğe güven ve geleceğe iyi bakma faktörleri ortalama puanları arasında istatistiksel açıdan anlamlı bir farklılık tespit edilemedi $(\mathrm{p} \geq 0,05)$. Sadece eğitim düzeyine göre öz kontrol faktörü ortalama puanları arasında farklılık tespit edildi ( $p=0,026 \leq 0,05)$. Eğitim düzeyine göre öz kontrol faktör değişkeninin homojenliğine ilişkin Levene testi sonucu anlamlıdır $(\mathrm{p} \geq 0,05)$. Bu sonuç eğitim düzeyi grupları arasında karşılaştırma yapılacağı anlamına gelmektedir. Çoklu karşılaştırma modeli olarak Tukey HSD kullanılmaktadır. Bu model ilköğretim mezunu çalışanların öz kontrolünün lise mezunu çalışanlara göre farklılık gösterdiği sonucunu ortaya koymaktadır. Ortalama değer incelendiğinde ise ilköğretim mezunu çalışan lise mezunu çalışana göre öz kontrolü yüksek davranmaktadır.

\section{Çizelge 8. Yaşa Göre Değişkenlerin Farklılığı}

\begin{tabular}{|c|c|c|c|c|c|c|}
\hline & Yaş & $n$ & $\bar{X}$ & $S S$ & $t$ & $p$ \\
\hline \multirow{2}{*}{ Psikolojik Sermaye } & $18-24$ yaş & 34 & 3,97 & 0,836 & \multirow{2}{*}{$-1,498$} & \multirow{2}{*}{0,137} \\
\hline & 25 yaş ve üstü & 88 & 4,20 & 0,701 & & \\
\hline \multirow{2}{*}{ Öz Yeterlilik ve Dayanıklık } & $18-24$ yaş & 34 & 3,98 & 0,877 & \multirow{2}{*}{$-1,281$} & \multirow{2}{*}{0,203} \\
\hline & 25 yaş ve üstü & 88 & 4,18 & 0,732 & & \\
\hline \multirow{2}{*}{ Umut } & $18-24$ yaş & 34 & 4,03 & 0,945 & \multirow{2}{*}{$-1,495$} & \multirow{2}{*}{0,137} \\
\hline & 25 yaş ve üstü & 88 & 4,27 & 0,730 & & \\
\hline \multirow{2}{*}{ Kariyer ve İş Adaptasyonu } & $18-24$ yaş & 34 & 4,01 & 0,777 & \multirow{2}{*}{$-1,885$} & \multirow{2}{*}{0,066} \\
\hline & 25 yaş ve üstü & 88 & 4,28 & 0,553 & & \\
\hline \multirow{2}{*}{ Güvengen Yetenekler ve Sosyal Sorumlukları Üstlenme Eğilimi } & $18-24$ yaş & 34 & 4,35 & 0,566 & \multirow{2}{*}{$-1,213$} & \multirow{2}{*}{0,228} \\
\hline & 25 yaş ve üstü & 88 & 4,48 & 0,498 & & \\
\hline
\end{tabular}


Zaman Algısı ve Bireysel Yükümlülük

Yeteneğe Güven ve Geleceğe İyi Bakma

Öz Kontrol

$\begin{array}{llllll}18-24 \text { yaş } & 34 & 4,13 & 0,846 & -1,521 & 0,131 \\ 25 \text { yaş ve üstü } & 88 & 4,35 & 0,655 & & \\ 18-24 \text { yaş } & 34 & 4,15 & 0,701 & -0,579 & 0,563 \\ 25 \text { yaş ve üstü } & 88 & 4,23 & 0,675 & & \\ 18-24 \text { yaş } & 34 & 3,76 & 0,996 & \mathbf{- 2 , 2 0 3} & \mathbf{0 , 0 3 3} \\ 25 \text { yaş ve üstü } & 88 & 4,17 & 0,704 & \end{array}$

Bağımsız Grup T Testi sonucunda, yaşa göre psikolojik sermaye değişkeni, öz yeterlilik ve dayanıklık, kariyer ve iş adaptasyonu değişkeni, güvengen yetenekler ve sosyal sorumlulukları üstlenme eğilimi, zaman algısı ve bireysel yükümlülük, yeteneğe güven ve geleceğe iyi bakma ve öz kontrol faktörleri ortalama puanları arasında istatistiksel açıdan anlamlı bir farklılık tespit edilemedi $(\mathrm{p} \geq 0,05)$. Yaşa göre umut faktörü $(\mathrm{p}=0,033 \leq 0,05)$ ortalama puanları arasında anlamlı bir farklılığa rastlanmaktadır. Ortalama değerlere bakıldığında 25 yaş ve üstü çalışanların umutları 18-24 yaş çalışanlara göre daha yüksektir

\section{Çizelge 9. İşyerindeki Çalışma Süresine Göre Değişkenlerin Farklılığı}

\begin{tabular}{|c|c|c|c|c|c|c|}
\hline & İşyerindeki Çalışma Süresi & $n$ & $\bar{X}$ & $S S$ & $t$ & $p$ \\
\hline \multirow{2}{*}{ Psikolojik Sermaye } & 1 y1ldan az & 65 & 4,06 & 0,761 & \multirow{2}{*}{$-1,252$} & \multirow{2}{*}{0,213} \\
\hline & 1 y1l ve üstü & 57 & 4,22 & 0,721 & & \\
\hline \multirow{2}{*}{ Öz Yeterlilik ve Dayanıklık } & 1 yildan az & 65 & 4,08 & 0,807 & \multirow{2}{*}{$-0,772$} & \multirow{2}{*}{0,442} \\
\hline & 1 y1l ve üstü & 57 & 4,18 & 0,744 & & \\
\hline \multirow{2}{*}{ Umut } & 1 yildan az & 65 & 4,09 & 0,778 & \multirow{2}{*}{$-1,767$} & \multirow{2}{*}{0,080} \\
\hline & 1 y1l ve üstü & 57 & 4,34 & 0,808 & & \\
\hline \multirow{2}{*}{ Kariyer ve İş Adaptasyonu } & 1 yildan az & 65 & 4,04 & 0,695 & \multirow{2}{*}{$-3,203$} & \multirow{2}{*}{0,002} \\
\hline & 1 yıl ve üstü & 57 & 4,39 & 0,497 & & \\
\hline \multirow{2}{*}{ Güvengen Yetenekler ve Sosyal Sorumlukları Üstlenme Eğ̈ilimi } & 1 yildan az & 65 & 4,37 & 0,555 & \multirow{2}{*}{$-1,602$} & \multirow{2}{*}{0,112} \\
\hline & 1 y1l ve üstü & 57 & 4,52 & 0,466 & & \\
\hline \multirow{2}{*}{ Zaman Alg1sı ve Bireysel Yükümlülük } & 1 yildan az & 65 & 4,14 & 0,805 & \multirow{2}{*}{$-2,640$} & \multirow{2}{*}{0,009} \\
\hline & 1 y1l ve üstü & 57 & 4,46 & 0,557 & & \\
\hline \multirow{2}{*}{ Yeteneğe Güven ve Geleceğe İyi Bakma } & 1 yildan az & 65 & 4,10 & 0,698 & \multirow{2}{*}{$-1,852$} & \multirow{2}{*}{0,067} \\
\hline & 1 y1l ve üstü & 57 & 4,32 & 0,644 & & \\
\hline \multirow{2}{*}{ Öz Kontrol } & 1 yıldan az & 65 & 3,89 & 0,812 & \multirow{2}{*}{$-2,504$} & \multirow{2}{*}{0,014} \\
\hline & 1 yıl ve üstü & 57 & 4,25 & 0,778 & & \\
\hline
\end{tabular}

Bağımsız Grup T Testi sonucunda, işyerindeki çalıșma süresine göre psikolojik sermaye değişkeni, öz yeterlilik ve dayanıklık ile umut faktörleri, güvengen yetenekler ve sosyal sorumlulukları üstlenme eğilimi, yeteneğe güven ve geleceğe iyi bakma faktörleri ortalama puanları arasında istatistiksel açıdan anlamlı bir farklılık tespit edilemedi $(\mathrm{p} \geq 0,05)$. İşyerindeki çalışma süresine göre kariyer ve iş adaptasyonu değişkeni $(p=0,002 \leq 0,01)$, zaman algısı ve bireysel yükümlülük faktörü $(p=0,009 \leq 0,01)$ ve öz kontrol $(\mathrm{p}=0,014 \leq 0,05)$ ortalama puanları arasında anlamlı bir farklılı̆ga rastlanmaktadır. Ortalama değerlere bakıldığında, 1 yıl ve üstü işyerinde çalışanların kariyer ve iş adaptasyonları, zaman algısı ve bireysel yükümlülük ile öz kontrolü 1 yıldan az işyerinde çalışanlara göre daha yüksektir.

\section{Çizelge 10. Toplam İş Tecrübesine Göre Değişkenlerin Farklılı̆̆ı}

\begin{tabular}{|c|c|c|c|c|c|c|}
\hline & Toplam Çalışma Süresi & $n$ & $\bar{X}$ & $S S$ & $t$ & $p$ \\
\hline \multirow{2}{*}{ Psikolojik Sermaye } & 5 y1l ve alt1 & 54 & 4,01 & 0,832 & \multirow{2}{*}{$-1,645$} & \multirow{2}{*}{0,103} \\
\hline & 6 yıl ve üstü & 68 & 4,24 & 0,656 & & \\
\hline \multirow{2}{*}{ Öz Yeterlilik ve Dayanıklık } & 5 y1l ve altı & 54 & 4,02 & 0,874 & \multirow{2}{*}{$-1,293$} & \multirow{2}{*}{0,199} \\
\hline & 6 yil ve üstü & 68 & 4,21 & 0,686 & & \\
\hline \multirow{2}{*}{ Umut } & 5 y1l ve altı & 54 & 4,08 & 0,876 & \multirow{2}{*}{$-1,618$} & \multirow{2}{*}{0,108} \\
\hline & 6 y1l ve üstü & 68 & 4,31 & 0,722 & & \\
\hline \multirow[t]{2}{*}{ Kariyer ve İş Adaptasyonu } & 5 y1l ve altı & 54 & 4,00 & 0,773 & \multirow[t]{2}{*}{$-3,152$} & \multirow[t]{2}{*}{0,002} \\
\hline & 6 yıl ve üstü & 68 & 4,37 & 0,434 & & \\
\hline
\end{tabular}




\begin{tabular}{|c|c|c|c|c|c|c|}
\hline Güvengen Yetenekler ve Sosyal Sorumlukları Üstlenme Eğilimi & $\begin{array}{l}5 \text { y1l ve altı } \\
6 \text { y1l ve üstü }\end{array}$ & $\begin{array}{l}54 \\
68\end{array}$ & $\begin{array}{l}4,37 \\
4,50\end{array}$ & $\begin{array}{l}0,542 \\
0,494\end{array}$ & $-1,446$ & 0,151 \\
\hline Zaman Algısı ve Bireysel Yükümlülük & $\begin{array}{l}5 \text { yıl ve altı } \\
6 \text { yıl ve üstü }\end{array}$ & $\begin{array}{l}54 \\
68\end{array}$ & $\begin{array}{l}4,10 \\
4,43\end{array}$ & $\begin{array}{l}0,864 \\
0,537\end{array}$ & $-2,458$ & 0,016 \\
\hline Yeteneğe Güven ve Geleceğe İyi Bakma & $\begin{array}{l}5 \text { yıl ve altı } \\
6 \text { yıl ve üstü }\end{array}$ & $\begin{array}{l}54 \\
68\end{array}$ & $\begin{array}{l}4,09 \\
4,29\end{array}$ & $\begin{array}{l}0,751 \\
0,609\end{array}$ & $-1,629$ & 0,106 \\
\hline Öz Kontrol & $\begin{array}{l}5 \text { yıl ve altı } \\
6 \text { yıl ve üstü }\end{array}$ & $\begin{array}{l}54 \\
68 \\
\end{array}$ & $\begin{array}{l}3,92 \\
4,17 \\
\end{array}$ & $\begin{array}{l}0,964 \\
0,656 \\
\end{array}$ & $-1,664$ & 0,100 \\
\hline
\end{tabular}

Bağımsız Grup T Testi sonucunda, toplam çalışma süresine göre psikolojik sermaye değişkeni, öz yeterlilik ve dayanıklık ile umut faktörleri, güvengen yetenekler ve sosyal sorumlulukları üstlenme eğilimi, yeteneğe güven ve geleceğe iyi bakma ile öz kontrol faktörleri ortalama puanları arasında istatistiksel açıdan anlamlı bir farklılık tespit edilemedi $(\mathrm{p} \geq 0,05)$. Toplam çalışma süresine göre kariyer ve iş adaptasyonu değişkeni ( $\mathrm{p}=0,002 \leq 0,01)$, zaman algısı ve bireysel yükümlülük faktörü $(\mathrm{p}=0,016 \leq 0,05)$ ortalama puanları arasında anlamlı bir farklılığa rastlanmaktadır. Ortalama değerlere bakıldığında, 6 yıl ve üstü işyerinde çalışanların kariyer ve iş adaptasyonları ile zaman algısı ve bireysel yükümlülükleri 5 yıl ve altı toplam iş tecrübesine sahip çalışanlara göre daha yüksektir.

\section{Çizelge 11. Çalıștığı Pozisyona Göre Değişkenlerin Farklılı̆̆ı}

\begin{tabular}{|c|c|c|c|c|c|c|}
\hline & Çalıştığ1 Pozisyon & $n$ & $\bar{X}$ & $S S$ & $t$ & $p$ \\
\hline \multirow{2}{*}{ Psikolojik Sermaye } & Beyaz Yaka & 31 & 4,29 & 0,568 & \multirow[b]{2}{*}{1,319} & \multirow{2}{*}{0,190} \\
\hline & Mavi Yaka & 91 & 4,08 & 0,792 & & \\
\hline \multirow{2}{*}{ Öz Yeterlilik ve Dayanıklık } & Beyaz Yaka & 31 & 4,32 & 0,548 & \multirow{2}{*}{1,997} & \multirow{2}{*}{$\mathbf{0 , 0 4 9}$} \\
\hline & Mavi Yaka & 91 & 4,06 & 0,833 & & \\
\hline \multirow{2}{*}{ Umut } & Beyaz Yaka & 31 & 4,18 & 0,725 & \multirow{2}{*}{$-0,245$} & \multirow{2}{*}{0,807} \\
\hline & Mavi Yaka & 91 & 4,22 & 0,826 & & \\
\hline \multirow{2}{*}{ Kariyer ve İş Adaptasyonu } & Beyaz Yaka & 31 & 4,32 & 0,400 & \multirow{2}{*}{1,556} & \multirow{2}{*}{0,123} \\
\hline & Mavi Yaka & 91 & 4,17 & 0,691 & & \\
\hline \multirow{2}{*}{ Güvengen Yetenekler ve Sosyal Sorumlukları Üstlenme Eğilimi } & Beyaz Yaka & 31 & 4,54 & 0,414 & \multirow{2}{*}{1,242} & \multirow{2}{*}{0,217} \\
\hline & Mavi Yaka & 91 & 4,41 & 0,548 & & \\
\hline \multirow{2}{*}{ Zaman Algısı ve Bireysel Yükümlülük } & Beyaz Yaka & 31 & 4,39 & 0,499 & \multirow{2}{*}{1,163} & \multirow{2}{*}{0,248} \\
\hline & Mavi Yaka & 91 & 4,25 & 0,776 & & \\
\hline \multirow{2}{*}{ Yeteneğe Güven ve Geleceğe İyi Bakma } & Beyaz Yaka & 31 & 4,19 & 0,512 & \multirow{2}{*}{$-0,208$} & \multirow{2}{*}{0,836} \\
\hline & Mavi Yaka & 91 & 4,21 & 0,731 & & \\
\hline \multirow{2}{*}{ Öz Kontrol } & Beyaz Yaka & 31 & 4,03 & 0,553 & \multirow{2}{*}{$-0,250$} & \multirow{2}{*}{0,803} \\
\hline & Mavi Yaka & 91 & 4,07 & 0,887 & & \\
\hline
\end{tabular}

Bağımsız Grup T Testi sonucunda, çalıştı̆̆ı pozisyona göre psikolojik sermaye değişkeni, umut, kariyer ve iş adaptasyonu değişkeni, güvengen yetenekler ve sosyal sorumlulukları üstlenme eğilimi, zaman algısı ve bireysel yükümlülük, yeteneğe güven ve geleceğe iyi bakma ile öz kontrol faktörleri ortalama puanları arasında istatistiksel açıdan anlamlı bir farklılık tespit edilemedi ( $\mathrm{p} \geq 0,05)$. Çalıştığı pozisyona göre öz yeterlilik ve dayanıklık faktörü ortalama puanları arasında anlamlı bir farklılığa rastlanmaktadır $(\mathrm{p}=0,049 \leq 0,05)$. Ortalama değerlere bakıldığında, beyaz yakalıların öz yeterlilik ve dayanıklıkları mavi yakalılara göre daha yüksektir.

\section{Çizelge 12. Gelir Düzeyine Göre Değișkenlerin Farklılı̆̆ı}

\begin{tabular}{|c|c|c|c|c|c|c|}
\hline & Gelir Düzeyi & $n$ & $\bar{X}$ & $S S$ & $t$ & $p$ \\
\hline \multirow{2}{*}{ Psikolojik Sermaye } & $2020-2500 \mathrm{TL}$ & 89 & 4,11 & 0,785 & \multirow{2}{*}{$-0,700$} & \multirow{2}{*}{0,485} \\
\hline & 2501 TL ve üstü & 33 & 4,21 & 0,624 & & \\
\hline \multirow{2}{*}{ Öz Yeterlilik ve Dayanıklılık } & $2020-2500 \mathrm{TL}$ & 89 & 4,09 & 0,821 & \multirow{2}{*}{$-0,782$} & \multirow{2}{*}{0,435} \\
\hline & 2501 TL ve üstü & 33 & 4,22 & 0,646 & & \\
\hline \multirow{2}{*}{ Umut } & $2020-2500 \mathrm{TL}$ & 89 & 4,21 & 0,831 & \multirow{2}{*}{0,091} & \multirow{2}{*}{0,927} \\
\hline & 2501 TL ve üstü & 33 & 4,20 & 0,717 & & \\
\hline \multirow{2}{*}{ Kariyer ve İş Adaptasyonu } & $2020-2500 \mathrm{TL}$ & 89 & 4,17 & 0,691 & \multirow{2}{*}{$-1,122$} & \multirow{2}{*}{0,265} \\
\hline & 2501 TL ve üstü & 33 & 4,29 & 0,435 & & \\
\hline
\end{tabular}




\begin{tabular}{|c|c|c|c|c|c|c|}
\hline \multirow{2}{*}{ Güvengen Yetenekler ve Sosyal Sorumlukları Üstlenme Eğilimi } & $2020-2500 \mathrm{TL}$ & 89 & 4,43 & 0,538 & \multirow{2}{*}{$-0,472$} & \multirow{2}{*}{0,638} \\
\hline & 2501 TL ve üstü & 33 & 4,48 & 0,469 & & \\
\hline \multirow{2}{*}{ Zaman Algısı ve Bireysel Yükümlülük } & $2020-2500 \mathrm{TL}$ & 89 & 4,28 & 0,780 & \multirow{2}{*}{$-0,163$} & \multirow{2}{*}{0,871} \\
\hline & 2501 TL ve üstü & 33 & 4,30 & 0,518 & & \\
\hline \multirow{2}{*}{ Yeteneğe Güven ve Geleceğe İyi Bakma } & $2020-2500 \mathrm{TL}$ & 89 & 4,20 & 0,730 & \multirow{2}{*}{$-0,229$} & \multirow{2}{*}{0,819} \\
\hline & 2501 TL ve üstü & 33 & 4,23 & 0,532 & & \\
\hline \multirow{2}{*}{ Öz Kontrol } & $2020-2500 \mathrm{TL}$ & 89 & 4,06 & 0,881 & \multirow{2}{*}{0,069} & \multirow{2}{*}{0,945} \\
\hline & 2501 TL ve üstü & 33 & 4,05 & 0,607 & & \\
\hline
\end{tabular}

Bağımsız Grup T Testi sonucunda, gelir düzeyine göre psikolojik sermaye değişkeni, öz yeterlilik ve dayanıklılık ile umut faktörleri, kariyer ve iş adaptasyonu değişkeni, güvengen yetenekler ve sosyal sorumlulukları üstlenme eğilimi, zaman algısı ve bireysel yükümlülük, yeteneğe güven ve geleceğe iyi bakma ile öz kontrol faktörleri ortalama puanları arasında istatistiksel açıdan anlamlı bir farklılık tespit edilemedi $(\mathrm{p} \geq 0,05)$.

\section{Basit ve Çoklu Doğrusal Regresyon Analizi}

Psikolojik sözleşmenin ve boyutlarının kariyer ve iş adaptasyonu ve boyutlarına etkisini belirlemek için Basit ve Çoklu Doğrusal Regresyon analizleri yapılmaktadır.

\section{Çizelge 13. Basit Doğrusal Regresyon Analizi Sonuçları}

\begin{tabular}{|c|c|c|c|c|c|c|}
\hline \multirow{2}{*}{ Bağımlı Değişken } & \multirow{2}{*}{ Bağımsız Değişken } & \multicolumn{2}{|c|}{ Standartlaştırılmamış Katsayı } & \multirow{2}{*}{$\frac{\text { Standartlaştırılmış Katsayı }}{\beta}$} & \multirow[b]{2}{*}{$t$} & \multirow[b]{2}{*}{$p$} \\
\hline & & $A$ & $\varepsilon_{S_{h}}$ & & & \\
\hline \multirow{2}{*}{ Zaman Algısı ve Bireysel Yükümlülük } & (Sabit) & 2,066 & 0,306 & & 6,745 & 0,000 \\
\hline & Psikolojik Sermaye & 0,538 & 0,073 & 0,558 & 7,371 & 0,000 \\
\hline
\end{tabular}

Psikolojik sermaye zaman algısı ve bireysel yükümlülüğün \%30,6'sını açıklamaktadır. Bağımsız değişkenin bağımlı değişken üzerindeki etkisini gösteren model, ANOVA testi sonuçlarına göre anlamlıdır ( $\mathrm{p}=0,000 \leq 0,01)$. Yukarıdaki tabloya göre sabit değerin ve bağımsız değişkenin katsayısı anlamlı olduğu görülmektedir $(\mathrm{p}=0,000 \leq 0,01)$. Psikolojik sermaye değişkenine ait regresyon yükü 0,538 ve standartlaştırılmış regresyon yükü de 0,558 'dir. Psikolojik sermaye çalışanlardaki zaman algısı ve bireysel yükümlülüğünü 0,538 puan yükseltmektedir. Psikolojik sermaye değişkeni zaman algısı ve bireysel yükümlülük değişkenini anlamlı bir şekilde yordamaktadır. Psikolojik sermeye ve kariyer adaptasyonu ile ilgili olarak öğrenciler üzerinde yapılan bir çalışmada öğrencilerin kariyer uyum yeteneği boyutları ile psikolojik sermaye boyutları arasında pozitif bir ilişki olduğu görülmektedir (Mercan, 2016). Safavi ve Bouzari (2019), psikolojik sermaye ile kariyer uyumu arasında önemli bir ilişki olduğunu kanıtlamıştır. Bu çalışmalarda ortaya çıkan sonuçla desteklenmektedir. Kalafat (2018), psikolojik dayanıklılık, kendini beğenme ve öz yeterlilik davranış1, kariyer uyum yeteneği, kariyer uyumu ve kariyer iyimserliğini etkilemektedir. Kalafat'ın çalışmasındaki analiz sonucu bu makaledeki analiz sonucu desteklememektedir. Ancak, sadece kendi kendine yeterliliğin kariyer iyimserliği üzerinde etkili olduğu belirlenmiştir. Kalafat'ın çalışmasındaki analiz sonucu bu makaledeki analiz sonucu desteklememektedir.

Basit doğrusal regresyon modeli: Zaman Algısı ve Bireysel Yükümlülük= 0,558*Psikolojik Sözleşme 
Çizelge 14. Çoklu Doğrusal Regresyon Analizi Sonuçları

\begin{tabular}{|c|c|c|c|c|c|c|}
\hline \multirow{2}{*}{ Bağımlı Değișken } & \multirow{2}{*}{ Bağımsız Değişken } & \multicolumn{2}{|c|}{ Standartlaştırılmamış Katsayı } & \multirow{2}{*}{$\begin{array}{c}\text { Standartlaştırılmış Katsayı } \\
\beta\end{array}$} & \multirow[b]{2}{*}{$t$} & \multirow[b]{2}{*}{$p$} \\
\hline & & $B$ & $\varepsilon_{S_{h}}$ & & & \\
\hline \multirow{3}{*}{$\begin{array}{l}\text { Zaman Algısı ve } \\
\text { Bireysel Yükümlülük }\end{array}$} & (Sabit) & 1,952 & 0,322 & & 6,064 & 0,000 \\
\hline & Öz Yeterlilik ve Dayanıklılık & 0,300 & 0,092 & 0,325 & 3,257 & 0,001 \\
\hline & Umut & 0,261 & 0,089 & 0,292 & 2,923 & 0,004 \\
\hline
\end{tabular}

Öz yeterlilik ve dayanıklık ile umut faktörleri zaman algısı ve bireysel yükümlülüğün \%30,2'sini açıklamaktadır. Bağımsız değişkenin bağımlı değişken üzerindeki etkisini gösteren model, ANOVA testi sonuçlarına göre anlamlıdır $(p=0,000 \leq 0,01)$. Yukarıdaki tabloya göre sabit değerin $(0,000 \leq 0,01)$, bağımsız değişkenlerden öz yeterlilik ve dayanıklık $(p=0,001 \leq 0,01)$ ile umut $(p=0,004 \leq 0,01)$ faktörlerinin katsayılarının anlamlı olduğu görülmektedir. Öz yeterlilik ve dayanıklık faktörüne ait regresyon yükü 0,300 ve standartlaştırılmış regresyon yükü de 0,325 ; umut faktörüne ait regresyon yükü 0,261 ve standartlaştırılmış regresyon yükü de 0,292'dir. Öz yeterlilik ve dayanıklık çalışanlardaki zaman algısı ve bireysel yükümlülüklerini 0,300, umut çalışanlardaki zaman algısı ve bireysel yükümlülükleri 0,261 puan yükseltmektedir. Öz yeterlik ve dayanıklık ile umut faktörleri birlikte zaman algısı ve bireysel yükümlülük faktörünü anlamlı bir şekilde yordamaktadır. Taş ve Alparslan (2020), insanın başarabileceğine dair özgüvene sahip olması, geleceğe ilişkin iyimserliği, zorluklara ilişkin direnç seviyesi ve hedefe doğru ilerlerken farklı yollar belirleme kapasitesine sahip olması, kişinin kariyerine ilişkin ilgisini, araştırmacı yönünü, merakını, özgüvenini ve kontrol algısını olumlu şekilde etkilemekte olduğunu belirtmişlerdir. Bu çalışmanın sonuçlarını desteklemektedir. Ndlovu ve Ferreira (2019), öğrencilerin psikolojik dayanıklılığı ile kariyer uyum yeteneği arasında bir ilişki olduğunu tespit etmiştir. Bu çalışmanın sonucunu desteklememektedir. Literatür taramasında psikolojik sermaye ve kariyer adaptasyonu değişkenlerinin birlikte ele alındığı ikili çalışmaların çok fazla olmaması nedeniyle sonuçların mukayesesi sınırlı kalmaktadır.

Çoklu doğrusal regresyon modeli: Zaman Algısı ve Bireysel Yükümlülük=0,325*Öz Yeterlilik ve Dayanıklık+ 0,292*Umut

\section{SONUÇ ve ÖNERILER}

Günümüzde işletmeler gelişen bilgi ve üretim teknolojilerinin getirdiği kolaylıklar nedeni ile üretimi zor olarak bilinen ürünler de dahil olmak üzere birçok ürünün üretimini daha kolay yapabilmektedir. Rekabetin arttığı bu dönemde makinalar nispeten aynı olsa da tüm insanların oldukça farklı özellikleri olduğu göz önünde bulundurulduğunda örgütte çalışanların örgüte kattıkları artı değerler ile rekabet üstünlüğü elde etmeleri önemli bir konu haline gelmiştir. İnsanlar sahip olduğu bireysel özellikteki farklı yetenekler, farklı üstünlükler ve farklı deneyimlerle bulundukları örgütleri diğer örgütlerden farklılaştırmaktadır. Bireylerin sahip oldukları psikolojik sermaye işletmelerin rekabet avantajı elde etmelerinde ekonomik, sosyal ve insan sermayesinden farklı olarak ön plana çıkmaktadır. Kişinin 
belirli bir sürede bilgi, deneyim, tecrübeleri ile oluşan bireysel farkındalığı ile ilişkili olan psikolojik sermayenin bireyin özellikle iş yaşamında verimliliğe etki edebileceği belirtilmektedir. Psikolojik sermayenin insanın sahip olduğu bu tecrübelerin pozitif yönde gelişimini sağlayarak kişinin sahip olduğu özelliklere artı değer katabileceği belirtilmektedir. Psikolojik sermayenin kişinin değişmesi zor olan durağan bireysel özelliklerinden farklı olarak geliştirilebilir olduğu vurgulanmaktadır.

Araştırmada psikolojik sermayenin, zaman algısı ve bireysel yükümlülük üzerinde etkisi ile öz yeterlik ve dayanıklık ve umudun zaman ve bireysel yükümlülük üzerinde etkisi tespit edilmiştir.

Psikolojik Sermayenin başka bir alt boyutu olan umuda sahip olan, bir işin başarılacağına olan umudunu koruyan çalışanlar pozitif düşünerek karşılaşılan farklı durumlarla ilgili bir çözüm bulabilmekte ve bireysel yükümlüklerini yerine getirmede başarılı olabilmektedir. Psikolojik sermeyenin alt boyutundan olan öz yeterlik ve dayanıklılık seviyesi yüksek olan, verilen bir vazifeyi mevcut yetkinlikleri ile başaracağına inanan, çabuk pes etmeyen, zorluklar ve farklı durumlar karşısında dayanıklılığı yüksek olan çalışanlar bireysel yükümlülüklerini istenilen zamanda yerine getirmede başarılı olabilmektedir. "Psychological Capital Research For Relations With Career Adaptability" adlı çalışmada öğrencilerin kariyer uyum yeteneği boyutlarından kaygı ile psikolojik sermaye boyutları olan güven, dışa dönüklük ve psikolojik dayanıklık arasında pozitif bir ilişki olduğu saptanmıştır (Mercan, 2016). Turizm sektöründe yapılan “The Association of Psychological Capital, Career Adaptability and Career Competency Among Hotel Frontline Employees” adlı araştırmada psikolojik sermaye artışının, çalışanların işe uyum sağlamasında, iş yaparken karşılaştıkları sorunları çözmede, işteki sorunları yönetmede çalışan davranışlarını olumlu olarak etkilediği belirtilmektedir. Güçlü psikolojik sermayenin kariyer adaptasyonuna etkisi olduğu belirtilmektedir (Safavi ve Bouzari, 2019). Psikolojik sermayenin kariyer adaptasyonuna etkisi yapılan bu çalışmalarda da yer almakta ve çalışmamızı desteklemektedir. Kalafat (2018), psikolojik dayanıklık, kendini beğenme ve öz yeterlik davranışı, kariyer uyum yeteneği, kariyer uyumu ve kariyer iyimserliğini etkilemektedir. Kalafat'ın çalışmasındaki analiz sonucu bu makaledeki analiz sonucu desteklememektedir. Ancak, sadece kendi kendine yeterliğin kariyer iyimserliği üzerinde etkili olduğu belirlenmiştir. Kalafat'ın çalışmasındaki analiz sonucu bu makaledeki analiz sonucu desteklememektedir. Ndlovu ve Ferreira (2019), öğrencilerin psikolojik dayanıklığı ile kariyer uyum yeteneği arasında bir ilişki olduğunu tespit etmiştir. Bu çalışmanın sonucunu desteklememektedir.

Araştırma sonuçlarına göre ilköğretim mezunu çalışan lise mezunu çalışana göre öz kontrolü yüksek davranmaktadır. İlköğretim mezunlarının iş bulmaları lise mezunlarına kıyasla daha zor olabilmektedir. Bu nedenle ilköğretim mezunlarının çalışmış oldukları işyerlerinde mevcut işlerini kaybetmemek adına kurumda istenmeyen davranışlardan kaçınıp istenen davranışları geliştirme yönlü 
hareket ettikleri düşünülmektedir. Mercanın çalışmasında öğrencilerin kariyer uyum yeteneği boyutlarından kontrol ile psikolojik sermaye boyutları olan iyimserlik arasında pozitif bir ilişki olduğu belirtilmektedir (Mercan, 2016). Bir yıl ve üstü işyerinde çalışanların kariyer ve iş adaptasyonları, zaman algısı ve bireysel yükümlülük ile öz kontrolü bir yıldan az işyerinde çalışanlara göre daha yüksektir. Bununla birlikte altı yıl ve üstü işyerinde çalışanların kariyer ve iş adaptasyonları ile zaman algısı ve bireysel yükümlülükleri beş yıl ve altı toplam iş tecrübesine sahip çalışanlara göre daha yüksektir. Toplam iş tecrübesi 6 yıl ve daha fazla olan çalışanların iş tecrübeleri 5yıl ve daha az çalışanlara göre daha fazla olduğu için kendilerine verilen görevlerin daha etkin yapıldığ 1 düşünülmektedir Araştırmaya katılanlar arasında gelir düzeyine göre psikolojik sermaye değişkeni, öz yeterlik ve dayanıklık ile umut faktörleri, kariyer ve iş adaptasyonu değişkeni, güvengen yetenekler ve sosyal sorumlulukları üstlenme eğilimi, zaman algısı ve bireysel yükümlülük, yeteneğe güven ve geleceğe iyi bakma ile öz kontrol faktörleri arasında bir farklılık olmadığı görülmüştür. Araştırmada 25 yaş ve üstü çalışanların umutları 18-24 yaş çalışanlara göre daha yüksek olduğu görülmektedir. Eğitim düzeyine göre psikolojik sermaye değişkeni, öz yeterlilik ve dayanıklık ve umut faktörü ile kariyer ve iş adaptasyonu değişkeni, güvengen yetenekler ve sosyal sorumlulukları üstlenme eğilimi, zaman algısı ve bireysel yükümlülük ile yeteneğe güven ve geleceğe iyi bakma arasında anlamlı bir farklılık tespit edilememiştir. Psikolojik sermayenin eğitim düzeyinden bağımsız olduğu, kişilerin kendi iç dinamikleri ile ilgili olduğu kişinin eğitim seviyesinin yüksek olmasının bu durumu değiştirmediği görülmektedir.

$\mathrm{Bu}$ araştırmanın değişkenleri psikolojik sermaye ve kariyer adaptasyonu ile ilgili olarak yapılan literatür taramasında az sayıda çalışmaya rastlandığı için sonuçların mukayesesi sınırlı kalmıştır. Ayrıca örneklem sayısının azlığı bir kısıt olarak düşünülebilir. Bu nedenle örneklem sayısı arttırılarak yeni çalışmaların yapılması önerilmektedir. Araştırmaların hem özel hem de kamu sektöründe yapılması ve birbirleriyle kıyaslanması sektöre katkı sağlayacaktır. İnsan kaynakları birimleri tarafından işe alım yapılırken, ilgili görevlere psikolojik sermeyesi güçlü kişilerin seçilmesinin yararlı olacağı ve işletme yönetimlerinin çalışanların psikolojik sermayesini güçlendirmek için teşvik edici önlemler almalarının ve uygulamalar yapmalarının da çalışanların verimine, dolayısıyla şirketlerin başarısına olumlu etki edeceği düşünülmektedir. 


\section{KAYNAKLAR}

Akçay, H.V.(2011). Pozitif Psikolojik sermayenin kişisel değerler bakımından iş tatminine etkisi ve bir araştırma, İstanbul Üniversitesi SBE Doktora Tezi ss.5-99

Akın A. Uysal, A. Ü. (2015). Olumlu düşünme becerileri ölçeğinin Türkçe formunun geçerlik ve güvenirliği, İktisat ve Girişimcilik Üniversitesi, Akademik Bakış Dergisi sayı: 51 Kırgızistan, Türk Dünyası Kırgız Türk Sosyal Bilimler Enstitüsü, s.266.

Al-Rawahia, B. (2016). Occupational Adjustment and its Correlation with Perceived SelfEfficacy among a Sample of Employees at the Directorate General of Education in Al-Dakhlyia Governorate, Jordan, University of Nizwa, master, pp 15-39.

Asia, K. (2018). Psikolojik sermayenin çalışanların iş performansına etkisi (Cezayir Elektrik ve Gaz Dağıtım Şirketi "Ouargla Dağıtım Müdürlüğü" örnek olay incelemesi, Cezayir, Kasadi Mirbah Üniversitesi, s.16

Cereci, C.(2019). The Old-Generation School Managers and the New-Generation School Managers From the Aspect of Career Adaptability, Vocational Identity and Career Construction in Education, 10.4018/978-1-5225-7772-0.ch009, pp. 160-177.

Cohen, J. (1988). Statistical Power Analysis for the Behavioral Sciences, 2nd Edition, Lawrence Erlbaum Associates Pbc. USA

Çetin F., Basım H. N. ( 2012). Örgütsel psikolojik sermaye Amme idaresi dergisi Cilt 45 say1 1, ss.123-124.

Demirci D. (2019). Çalışanların örgütsel destek algılarının örgütsel vatandaşlık davranışlarına etkileri: Psikolojik sermayenin bu süreçteki rolü ve bir araştırma Doktora Tezi İnönü Üniversitesi SBE, s. 175.

Erdem H. Gökmen Y. Türen U. (2015). Psikolojik sermayenin örgütsel özdeşleşme üzerine etkisinde algılanan örgütsel desteğin aracılık rolü. İşletme Araştırmaları Dergisi, Say1 1309-0712 ss. 41-42.

Erkuş A, Fındıklı M.A, Psikolojik sermayenin iş tatmini, iş performansı ve işten ayrılma niyeti üzerindeki etkisine yönelik bir araştırma, İstanbul Üniversitesi İşletme Fakültesi Dergisi Cilt 42 Sayı 2 s.304.

Ertosun Ö. G (2016). Pozitif Psikolojik Sermayenin İş Algısı Bireye ve işe yönelik çıktılarla ilişkisinin incelenmesi: Deneysel Amprik bir çalışma Doktora tezi Gebze Teknik Üniversitesi SBE ss. 16-17.

Fahjan,S. (2010). Identify the compatibility of professional and social responsibility, master, Palestine, Islamic University, p.39.

Feki, I. (2014). Time Management, Wael Publishing House, p.23. 
İspir, Ö. ve diğ..(2019). The relationship of personality traits and entrepreneurship tendencies with career adaptability of nursing students, Nurse Education Today, 10.1016/j.nedt.2019.05.017.

Kafrouny, N. (2016) Originality of thinking and their relationship motivated by curiosity, master, Damascus University, p. 36

Kalafat, T. (2018). Kariyer Uyumu ve Kariyer İyimserliğinin Psikolojik Dayanıklılık ve Benlik Saygısı ile İlgili Bileșenleri, Uluslararası İnsan ve Davranış Bilimleri Dergisi, 4(2), s.31-41.

Kalaycı, Ş. (2008). SPSS Uygulamalı Çok Değişkenli İstatistik Teknikleri, Ankara: Asil Yayın Dağıtım.

Kaya Ç.ve diğ. ( 2014). Turkish Version of Career And Work Adaptability Quastionna (CWAQ): Validty and Reliability Study, E-İnternational Journal of Educational Research, p. 84.

Laura N. ve diğ.(2012). The Career and Work Adaptability Questionnaire (CWAQ): A first contribution to its validation, Journal of Adolescence, Volume 35, Issue 6, December 2012, Pages 1557-1569

Levene, R.A.(2015) Positive Psychology At Work: Psychological Capital and Thriving as Pathways to Employee Engagement, University of Pennsylvania, August 1, 2015, ScholarlyCommons, Master of Applied Positive Psychology (MAPP) Capstone Projects, pp. 2-46.

Litman, J.A.(2007). Curiosity As A Feeling Of Interest And Feeling Of Deprivation :The I/D Model Of Curiosity,Issues In The Psychologhy Of Motivation,NovaScience Publishers,pp.149-156.

Luthans, F. (2007). "Hope, Optimism and Other Business Assets: Why PsychologicalCapital is so Valuable to Your Company" Gallup Business JournalInterview with Fred Luthans, January 11, http://gmj.gallup.com

Luthans, F. (2002). Positive organizational behavior: Developing and managing psychological strengths, Academy of Management Executive, pp. 57-72.

Mercan N.(2016). Psikolojik sermayenin kariyer uyum yeteneği ile ilişkisine yönelik bir araştırma, Global Business Research Congress, May 26-27, 2016 İstanbul, Turkey, ISSN: 2459-0762

Ndlovu, V. ve Ferreira, N. (2019). Students' psychological hardiness in relation to career adaptability. Journal of Psychology in Africa, 29(6), p.598-604.

Nota, L. ve diğ.(2012). The Career and Work Adaptability Questionnaire (CWAQ): A first contribution to its validation, Journal of Adolescence, Volume 35, Issue 6, December 2012, pp 1557-1569 
Rochat, S. ve diğ. (2017). Determining Career Resilience, Psychology of Career Adaptability, Employability and Resilience, 10.1007/978-3-319-66954-0_8, pp 125-141.

Prajapati, B. ve diğ. (2010). Sample Size Estimation and Statistical Power Analysis, Optometry Today, 16(7), 1-9.

Rottinghaus, P.J ve diğ.(2011) Journal of Career Assesment Volume: 20 issue: 2, pp. 123 139.

Safavi, H. P, Bouzari, M. (2019). The association of psychological capital, career adaptability and career competency among hotel frontline employees. Tourism Management $\quad$ Perspectives, 30 (February), 65-74. https://doi.org/10.1016/j.tmp.2019.02.001

Saleh, R. (2016), Psikolojik sermayenin örgütsel bağlılığa ulaşma üzerindeki etkisi (Basra'daki Gübre Sanayii Genel Şirketi'nde yapılan bir saha çalışması) . Basra Üniversitesi, İşletme ve Ekonomi Fakültesi. İktisadi Bilimler Dergisi ,Cilt: 10, , Say1: 41, s.8

Savickas M. L. (1997). Career Adaptability: An Integrative Construct for Life-Span, LifeSpace Theory pp:247-259

Şahin Z. (2014), Kriz Yönetimi ve psikolojik sermaye arasındaki ilişki Harran üniversitesi SBE. s.69

Taber B.J (2019), Career Counselling Interventions to Enhance Career Adaptabilities for Sustainable Employment, Handbook of Innovative Career Counselling pp 103115.

Taş, M.A. ve Alparslan, M. A.(2020). Kültürel Değerler, Psikolojik Sermaye ve Kariyer Uyum Yeteneği İlişkisine Dair Bir Saha Araştırması. Celal Bayar Üniversitesi Sosyal Bilimler Dergisi, 18 (Özel Sayı), 417-440.

Topaloğlu, T. Psikolojik sermaye: Psikolojik sermaye ile iş performansı arasındaki ilişkiye otantik liderliğin düzenleyici etkisi, Sosyal Bilimler Enstitüsü, Dokuz Eylül Üniversitesi, İzmir, s.21

Zağlı, A. (2016). Psikolojik sermayenin çalışanın stresle başa çıkma, iş tatmini ve örgütsel bağlılığına etkisi. Muğla Büyük Şehir Belediyesi örneği Muğla Sitkı Koçman Üniversitesi s.30

Zhao, Z. and Hou, J. (2009). The study on psychological capital development on intrapreneurial team. International Journal of Psychological Studies, 1(2), pp.3540.

Zorver, C.E. (2011). Kariyer Uyumu ve İyimserlik ölçeğinin geliştirilmesi, Sosyal Bilimler Enstitüsü, Hacettepe üniversitesi Ankara, s.39. 